\title{
BASEMENT CHARACTERISTICS IN THE LOWER MAGDALENA VALLEY AND THE SINÚ AND SAN JACINTO FOLD BELTS: EVIDENCE OF A LATE CRETACEOUS MAGMATIC ARC AT THE SOUTH OF THE COLOMBIAN CARIBBEAN
}

\author{
CARACTERÍSTICAS DEL BASAMENTO EN EL VALLE INFERIOR DEL MAGDALENA Y \\ CINTURONES PLEGADOS DE SINÚ Y SAN JACINTO: EVIDENCIAS DE UN ARCO MAGMÁTICO \\ DEL CRETÁCICO TARDÍO EN EL CARIBE SUR COLOMBIANO

\section{CARACTERÍSTICAS DO SUBSOLO NO VALE INFERIOR DO MAGDALENA E NAS FAIXAS DE DOBRAMENTO DE SINÚ E SAN JACINTO: EVIDÊNCIA DE UM ARCO MAGMÁTICO DO CRETÁCICO TARDIO NO SUL DO CARIBE COLOMBIANO}

Alejandro Silva-Arias ${ }^{1 *}$; Liliana-Andrea Páez-Acuña ${ }^{2}$; Daniel Rincón-Martínez ${ }^{1}$; Javier-Alfonso Tamara-Guevara ${ }^{3}$; Pedro-David Gomez-Gutierrez'; Eduardo López-Ramos'; Sandra-Milena Restrepo-Acevedo ${ }^{1}$; Luis-Carlos Mantilla-Figueroa ${ }^{2}$ and Victor Valencia ${ }^{5}$

\footnotetext{
' ECOPETROL S.A., Instituto Colombiano del Petróleo (ICP), Colombia

2 Universidad Industrial de Santander, Bucaramanga, Santander, Colombia, Escuela de Geología.

3 Royal Holloway. University of London, England.

${ }^{4}$ ECOPETROL S.A. Gerencia de Exploración Offshore, Colombia.

${ }^{5}$ School of Earth and Environmental Sciences, Washington State University, Pullman, USA.
}

e-mail: daniel.rincon@ecopetrol.com.co

\begin{abstract}
(Received: Dec. 22, 2015; Accepted: Dec 09, 2016)

he onset of subduction in the Caribbean Plate under the South American Plate allowed the development of an Active Continental Margin; the age of onset, the mechanism and the plates involved are a discussion topic, especially at the Colombian South Caribbean Margin, due to the lack of geological information related to the basement. This article integrates petrographic, geochemical analyses and $\mathrm{U} / \mathrm{Pb}$ dating of basement samples, in addition to the inclusion of published magnetic anomalies maps from the North of Colombia, in order to generate a compositional distribution map of the basement and determine the presence of a magmatic arc under the sediments of the Lower Magdalena Valley (LMV), which supports the existence of a Late Cretaceous active continental margin represented by a magmatic arc, called Magmatic Arc of Magangué. Dating of the arc yield a Late Cretaceous Age (84-74 Myr), and petrographic and geochemical evidence suggests it is comprised of igneous bodies of felsic to intermediate composition, which intrude the LMV continental crust, originated in a subduction setting. The origin of the LMV continental crust seems to be related to the continent-continent collision (consolidation of Pangaea) during the Permian (300 Ma ago), and to the post-Alleganian extension event of Triassic age (232 Ma ago).
\end{abstract}

Keywords: Magmatic Arc, U-Pb geochronology, subduction, Caribbean, South America.

How to cite: Silva-Arias, A., Páez-Acuña, L. A., Rincón-Martínez, D., Tamara-Guevara, J. A., Gomez-Gutierrez, P. D., López-Ramos, E., Restrepo-Acevedo, S. M., Mantilla-Figueroa, L. C., \& Valencia, V. (2016). Basement characteristics in the Lower Magdalena Valley and the Sinú and San Jacinto Fold Belts: Evidence of a Late Cretaceous Magmatic Arc at the South of the Colombian Caribbean. CT\&F - Ciencia, Tecnología y Futuro, 6(4), 5-36.

*To whom correspondence should be addressed 


\section{RESUMEN}

$\mathrm{E}$

I inicio de la subducción de la Placa Caribe bajo la Placa Suramericana permitió el desarrollo de una Margen Continental Activa; la edad de inicio, el mecanismo y las placas involucradas son tema de debate en especial en el Margen Caribe Sur colombiano, debido a la falta de información geológica del basamento. En este artículo se integran análisis petrográficos, geoquímicos y dataciones $\mathrm{U} / \mathrm{Pb}$ de muestras del basamento, además de la inclusión de mapas de anomalías magnéticas publicados del Norte de Colombia, para generar un mapa de distribución composicional del basamento y determinar la existencia de un arco magmático bajo los sedimentos del Valle Inferior del Magdalena (VIM) que apoyan la existencia de una Margen Continental Activa desde el Cretácico Tardío. La existencia de este arco, denominado como Arco Magmático de Magangué de edad Cretácico Tardío (84-74 Ma), está compuesto por cuerpos ígneos de composición félsica a intermedia que intruyen la corteza continental del VIM, originados en un ambiente de subducción. El origen de la corteza continental del VIM parece estar ligada a la colisión continentecontinente (consolidación de Pangea) durante el Pérmico (300Ma), y al evento de extensión post-Alleganiano de edad Triásica (232Ma).

Palabras clave: Arco Magmático, geocronología U-Pb, subducción, Caribe, Sur América.

\section{RESUMO}

início da subducção da Placa Caribe sob a Placa Sul-americana possibilitou o desenvolvimento de
uma Margem Continental Ativa; a idade de início, o mecanismo e as placas envolvidas fazem parte
do âmbito de discussão no que tange especialmente à Margem Caribe Sul colombiana, devido à
falta de informação geológica do subsolo. Este artigo integra análises petrográficos, geoquímicos e dataçães
U/Pb de amostras do subsolo, incluindo também mapas de anomalias magnéticas publicados do Norte da
Colômbia, visando a criação de um mapa de distribuição composicional do subsolo e a determinação da
existência de um arco magmático sob os sedimentos do Vale Inferior do Magdalena (VIM) que suportam a
existência de uma Margem Continental Ativa desde o Cretácico Tardio. A existência deste arco, denominado
como Arco Magmático de Magangué de idade Cretácico Tardio (84-74 Ma), é composta por corpos
ígneos de composição félsica e intermédia que intrudem a crosta continental do VIM, originados em um
ambiente de subducção. A origem da crosta continental do VIM parece estar relacionada com a colisão
continente-continente (consolidação de Pangeia) durante o Pérmico (300Ma), e com o evento de extensão
pos-alleganiano da era Triásica (232Ma).

Palavras-chave: Arco Magmático, geocronologia U-Pb, subducção, Caribe, América do Sul. 


\section{INTRODUCTION}

The tectonic evolution of NW South America, between the Permian and Late Cretaceous-Paleogene, was related to the complex interaction of South American, Caribbean (Plateau and proto-Caribbean) and Farallones plates. The Permian recorded the Pangaea consolidation and the Allaganian Mountains generation (Condie \& Sloan, 1997; Yañez, Ruiz, Patchett, OrtegaGutierrez, \& Gehrels, 1991). During the Triassic, the post-Alleganian event marked the rifting onset between Gondwana-Laurentia. Meanwhile, for the JurassicLate Cretaceous intra-continental rift (E.g. Cediel, Shaw, \& Caceres, 2003 Pindell \& Kennan, 2009) or extensional subduction scenarios (E.g. Aspden et al., 1987; Villagómez et al., 2011; Cochrane et al., 2014) have been set out. Two tectonic models explain the geological evolution in the area after these events. First, the allochthone-related models that suggest a Caribbean plate origin (Plateau) linked to the Pacific Plate geological history (E.g. Pindell et al., 1988; Pindell, 1990; Mann et al., 2002; Pindell \& Kennan, 2009; Escalona \& Mann; 2011). In such models, the NW South America is considered a passive margin between 120 and 84 Myr; and for the Late Cretaceous suggest an arc-continent collision between the Caribbean plate (Plateau) and South America. This collision must have given rise to oceanic crust subduction (Pacific-originated Plateau) occurring since the Campanian (approximately 72 Myr ago; Cediel et al., 2003). On the other hand, autochtone-related models assume that the Caribbean plate was formed between North America and South America. In autochtonous models, subduction is restricted to the proto-Caribbean opening during the Jurassic-Late Cretaceous, and the continental margin starts to behave actively since the Late Cretaceous (8670 Myr) (E.g. Ball et al., 1969; Aubouin et al., 1982; Sykes et al., 1982; Donnelly, 1985; Meschede \& Frisch, 1998; James, 2006).

In both scenarios of allochtonous/autochtonous origin, the southeastern margin of the Caribbean/protoCaribbean plate is characterized by an intra-oceanic arc system called the "Great Caribbean Arc" (sensu Burke, Fox, \& Sengor, 1978; Burke, 1988). At the beginning, it was proposed that crystalline rocks from the Greater Antilles, Ave Ridge, Lesser Antilles and Dutch-Venezuelan Antilles represented a single history of the Caribbean Arc (sensu Burke et al., 1978; Burke,
1988). However, some researchers treat these Great Arc components as separate entities, given that they appear to have different tectonic histories and have started as individual arc systems at different times during the Cretaceous through Paleogene (E.g Wright \& Wyld 2011; Xie \& Mann, 2014).

Finally, and also valid for both, the autochtonous and the allochtonous models during the Cenozoic the region is characterized by accretionary prisms occurence, which NE oriented faults activation and small oceanic crust sections attached to the continental margin of Ecuador, Colombia and Venezuela, suggest a behavior similar to an active margin (E.g. Santamaría \& Schubert, 1974; Duque-Caro, 1984; Taboada et al., 2000; Vallejo et al., 2006; Cerón, Kellogg, \& Ojeda, 2007; MantillaPimiento, 2007; Toro, Gómez, \& Moreno, 2014).

At the north of Colombia (Figure 1), evidence of an active continental margin during the Late Cretaceous, have been reported in magmatic bodies emplaced at the North of the Cordillera Central (CC) (E.g. Ordóñez \& Pimentel, 2001a, b; Restrepo-Moreno et al., 2007a, b; Ordoñez, Pimentel, \& Laux, 2008; Villagómez et al., 2011), and in the Guajira Peninsula (PG; Cediel et al., 2003; Weber et al., 2009, 2011). However, in other continental margin areas, such as the Lower Magdalena Valley (LMV), there are no reports of igneous activity for the same period and therefore; it has not been considered as part of the geodynamic history. This is a peculiar fact given that for many authors (i.e. Duque-Caro, 1979; Flinch, 2003; López \& Barrero, 2003; Cerón et al., 2007) this area is located at the transpressional limit which connected the terranes of the Great Caribbean Arc, the Caribbean plate front limit and the South America North margin.

This article integrates information from petrographic analyses of basement samples (crystalline metamorphic and plutonic rocks) from exploratory wells in LMV and outcrops in the San Jacinto Fold Belt (SJFB) area, along with some geochronological dating and geochemical analyses, in addition to a qualitative analysis of magnetic anomalies maps (i.e. Graterol, 2006; Mantilla-Pimiento, 2007). The integration of this information allowed the correlation of basement lithologies existence with magnetic anomalies, providing the basis for a compositional distribution map of the igneousmetamorphic basement and to propose the existence of 


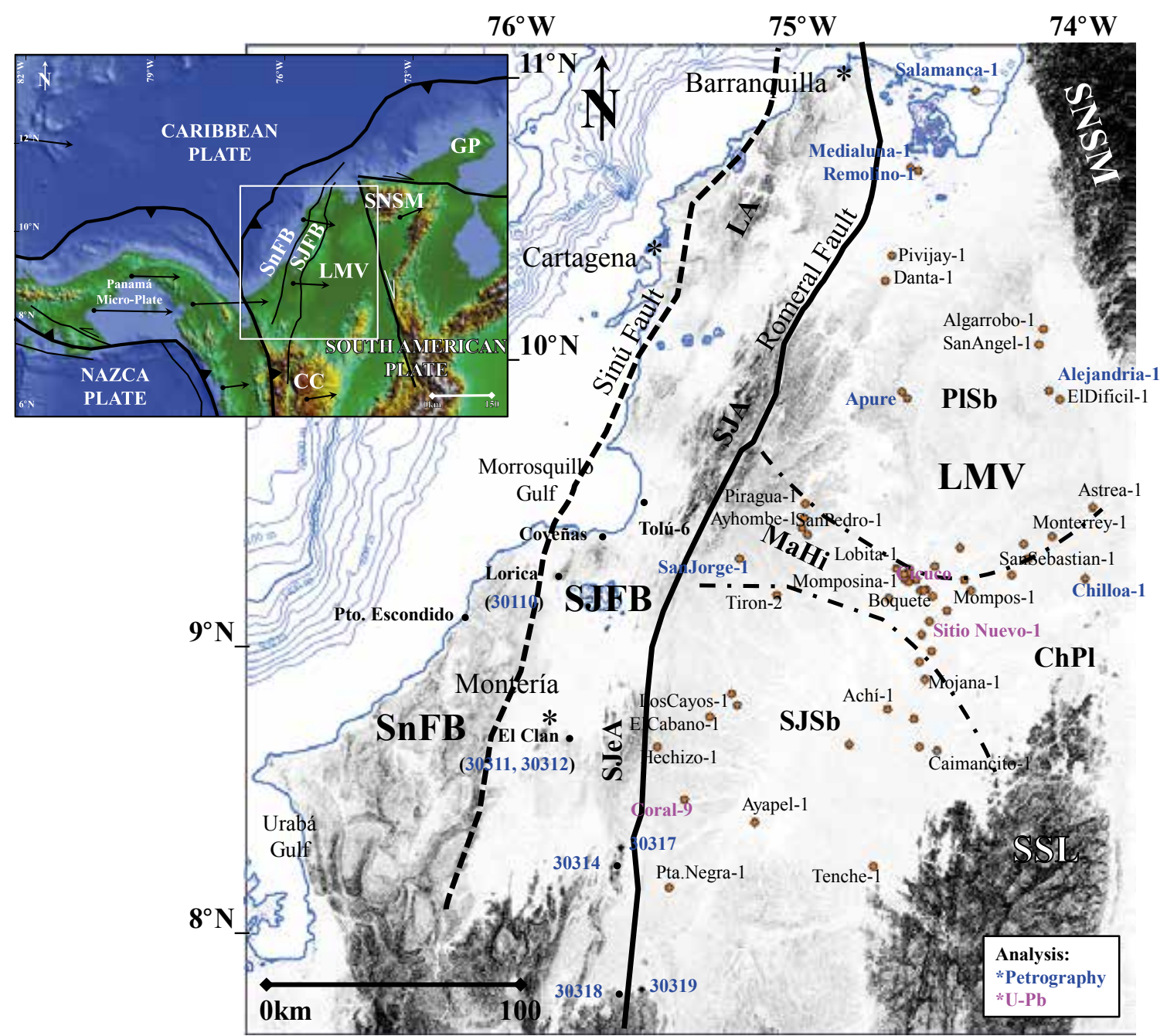

Figure1. Location map of exploratory wells that drilled basement (Cerón et al., 2007). Also includes the analyses developed in some of the wells and the location of two SJFB outcrops sampled in this study. SnFB: Sinú Fold Belt; SJFB: San Jacinto Fold Belt; SJeA: San Jerónimo Anticline; SJA: San Jacinto Anticline; LA: Luruaco Anticline; LMV: Lower Magdalena Valley; SJsB: San Jorge sub-Basin; PlsB: Plato sub-Basin; MaHi: Magangué High; ChPl: Chimichagua Platform; SNSM: Sierra Nevada de Santa Marta; SLR: San Lucas Range; GP: Guajira Peninsula.

a magmatic arc in the continental margin at the North of Colombia, specifically in the LMV.

\section{Geological framework}

The study area comprises SJFB, part of the Sinú Fold Belt (SnFB), and LMV (Figure 1). The SJFB is between LMV and SnFB, and is separated from them by the Romeral Fault (Northern prolongation of the Romeral Fault System; Grosse, 1926 in: Kammer, 1993; Duque-Caro, 1980; Camargo, 1995; Reyes \& Camargo, 1995; Reyes \& Clavijo, 1996 in: Ujueta-Lozano, 2007) and the Sinú Fault (Duque-Caro, 1979; Camargo, 1995; Reyes \& Camargo, 1995; Reyes \& Clavijo, 1996 in: Ujueta-Lozano, 2007), respectively. It encompasses the
San Jacinto (SJA) and San Jerónimo (SJeA) anticlines, and it is approximately $360 \mathrm{~km}$ long and $60 \mathrm{~km}$ wide, with a $\mathrm{N} 20^{\circ} \mathrm{E}$ trend at the surface (Figure 1; DuqueCaro, 1984). The SnFB is part of the Sinú Accretionary Wedge, which extends to the Colombian offshore, and to the east, it is separated from SJFB by the Sinú Fault (Figure 1). The SnFB is over $500 \mathrm{~km}$ long and about $125 \mathrm{~km}$ wide. Finally, LMV is delimited to the west by the Romeral Fault and to the east by the BucaramangaSanta Marta fault. It is sub-divided in the Plato sub-basin (PlsB), to the North, and the San Jorge sub-basin (SJsB), to the South, both separated by the Magangué High (MaHi), which, according to Barrero, Pardo, Vargas, \& Martínez, (2007), controlled the sedimentation in the two depocenters since the Eocene to Late Miocene. 
The LMV basement has been interpreted as a continental crust integrated by intrusive and extrusive igneous rocks, and metamorphic rocks (INGEOMINAS, 1997; ICP, 2000; Cerón et al., 2007). The oceanicaffinity basement is exposed in isolated blocks in SJFB (Dueñas \& Duque-Caro, 1981; Duque-Caro, 1984; Guzmán, 2007: Cerón et al., 2007; Lara et al., 2013). The tectonic limit or suture between the continental crust, to the East, and the considered allochthonous, accretionated terrane of SJFB has been established as the Romeral Fault System (Laverde, 2000). Further West, in the offshore Colombian basin, the seismic refraction and gravity data have identified an anomalously thick oceanic basement with thicknesses of 8 to $>20 \mathrm{~km}$ (Donnelly, 1994), which consists on a Cretaceous complex of basalt and diabase flows interbedded with sedimentary rocks (Driscoll \& Diebold, 1999).

\section{METHODOLOGY}

This study incorporated the petrographic information of 60 exploratory wells (Cerón et al., 2007) and was updated with the inclusion of 14 new petrographic analyses from nine wells (Table 1, Figure 1). Additionally, field work was carried out in the localities of Puerto Escondido, Lorica, Montería and San Jerónimo to the south of SJFB, in order to take samples and verify the nature of outcropping crystalline rocks, through their petrographic characterization (Table 1). The wells and outcrops samples were classified using a 250-point

Table1. Thin sections analyzed in this study (Figure 1), location, sample type and petrographic description (NA: Not Available; ${ }^{*}$ : petrographic description taken from Cerón et al., 2007).

\begin{tabular}{|c|c|c|c|c|c|c|}
\hline \multirow{2}{*}{\multicolumn{2}{|c|}{$\begin{array}{l}\text { Well / Localition } \\
\text { (sample) }\end{array}$}} & \multicolumn{2}{|c|}{ Coordinates } & \multirow{2}{*}{$\underset{(\mathrm{m})}{\text { Depth }}$} & \multirow{2}{*}{$\begin{array}{l}\text { Sample } \\
\text { type }\end{array}$} & \multirow{2}{*}{$\begin{array}{l}\text { Petrographic } \\
\text { Description }\end{array}$} \\
\hline & & Lat: N & Long: W & & & \\
\hline \multicolumn{2}{|c|}{ Alejandría-1 } & $9^{\circ} 54^{\prime} 57.97^{\prime \prime}$ & $74^{\circ} 07^{\prime} 49.02^{\prime \prime}$ & 2023.9 & Well (Cuttings) & Granodiorite \\
\hline \multirow{4}{*}{\multicolumn{2}{|c|}{ Apure-1 }} & & & 3468.6 & Well (Cuttings) & Basalt \\
\hline & & $9^{\circ} 53^{\prime} 16.45^{\prime \prime}$ & $74^{\circ} 37^{\prime} 51.62^{\prime \prime}$ & 3493.0 & Well (Cuttings) & Basalt \\
\hline & & & & 3773.4 & Well (Cuttings) & Andesite \\
\hline & & & & 3779.5 & Well (Cuttings) & Andesite \\
\hline \multicolumn{2}{|c|}{ Cicuco-2 } & $9^{\circ} 16^{\prime 2} 24.71^{\prime \prime}$ & $74^{\circ} 37^{\prime} 53.07^{\prime \prime}$ & 2401.8 & NA & Monzogranite* \\
\hline \multicolumn{2}{|c|}{ Cicuco-3 } & $9^{\circ} 16^{\prime 38.58 "}$ & $74^{\circ} 37^{\prime} 51.91^{\prime \prime}$ & 2433.2 & NA & Tonalite* \\
\hline \multirow{3}{*}{\multicolumn{2}{|c|}{ Cicuco-22 }} & & & 2506.4 & Well (Core) & Syenogranite* \\
\hline & & $9^{\circ} 15^{\prime} 9.35^{\prime \prime}$ & $74^{\circ} 36^{\prime} 5.03^{\prime \prime}$ & 2507.6 & Well (Core) & Syenogranite* \\
\hline & & & & 2509.4 & Well (Core) & Syenogranite* \\
\hline \multicolumn{2}{|c|}{ Cicuco-24 } & $9^{\circ} 17^{\prime} 20.71^{\prime \prime}$ & $74^{\circ} 37^{\prime} 42.41^{\prime \prime}$ & 2459.1 & NA & Granodiorite* \\
\hline \multicolumn{2}{|c|}{ Chilloa-1 } & $9^{\circ} 15^{\prime} 22.73^{\prime \prime}$ & $74^{\circ} 00^{\prime} 6.96^{\prime \prime}$ & 591.3 & Well (Cuttings) & Monzogranite \\
\hline \multicolumn{2}{|c|}{ Coral-9 } & $8^{\circ} 28^{\prime} 45.31^{\prime \prime}$ & $75^{\circ} 25^{\prime} 9.39^{\prime \prime}$ & 3130.3 & Well (Cuttings) & Monzogranite \\
\hline \multirow{3}{*}{\multicolumn{2}{|c|}{ Lobita- 1}} & & & 2526.8 & NA & Granodiorite* \\
\hline & & $9^{\circ} 17^{\prime} 30.89^{\prime \prime}$ & $74^{\circ} 40^{\prime} 30.83^{\prime \prime}$ & 2060.4 & Well (Cuttings) & Diorite \\
\hline & & & & 2074.2 & Well (Cuttings) & Quartz diorite \\
\hline \multicolumn{2}{|c|}{ Salamanca- 1} & $10^{\circ} 58^{\prime} 8.32^{\prime \prime}$ & $74^{\circ} 23^{\prime} 38.06^{\prime \prime}$ & 2367.1 & Well (Cuttings) & Quartz diorite \\
\hline \multicolumn{2}{|c|}{ San Sebastian-1 } & $9^{\circ} 16^{\prime} 7.48^{\prime \prime}$ & $74^{\circ} 15^{\prime} 49.16^{\prime \prime}$ & 1179.6 & Well (Cuttings) & Sublitharenite/Syenogranite \\
\hline \multirow{3}{*}{\multicolumn{2}{|c|}{ Sitio Nuevo-1 }} & & & 1216.2 & Well (Cuttings) & Quartz syenite* \\
\hline & & $9^{\circ} 03^{\prime} 34.63^{\prime \prime}$ & $74^{\circ} 34^{\prime} 46.41^{\prime \prime}$ & 1618.9 & Well (Core) & Gabbro \\
\hline & & & & 1624.6 & Well (Core) & Pyroxenite \\
\hline \multicolumn{2}{|c|}{ Remolino-1 } & $10^{\circ} 41^{\prime} 11.93^{\prime \prime}$ & $74^{\circ} 35^{\prime} 35.41^{\prime \prime}$ & 1953.8 & Well (Core) & Andesite \\
\hline Lorica & $30110-2$ & $9^{\circ} 14^{\prime} 46.33^{\prime \prime}$ & $75^{\circ} 47^{\prime} 25.22^{\prime \prime}$ & 0.0 & Outcrop & Diorite/Gabbro/Anorthosite \\
\hline \multirow{4}{*}{$\begin{array}{l}\text { San } \\
\text { Jerónimo }\end{array}$} & 30313-1 & $8^{\circ} 14^{\prime} 26.68^{\prime \prime}$ & $75^{\circ} 37^{\prime} 57.21^{\prime \prime}$ & 0.0 & Outcrop & Basalt \\
\hline & $30314-2$ & $8^{\circ} 15^{\prime} 55.88^{\prime \prime}$ & $75^{\circ} 37^{\prime} 54.88^{\prime \prime}$ & 0.0 & Outcrop & Serpentinite \\
\hline & $30317-1$ & $8^{\circ} 18^{\prime} 20.84^{\prime \prime}$ & $75^{\circ} 3833.67^{\prime \prime}$ & 0.0 & Outcrop & Serpentinite \\
\hline & $30319-1$ & $7^{\circ} 48^{\prime} 26.45^{\prime \prime}$ & $75^{\circ} 33^{\prime} 59.33^{\prime \prime}$ & 0.0 & Outcrop & Serpentinite \\
\hline Tarazá & $30325-2$ & $7^{\circ} 28 ' 32.62^{\prime \prime}$ & $75^{\circ} 19^{\prime} 44.67^{\prime \prime}$ & 0.0 & Outcrop & Tonalite \\
\hline
\end{tabular}


count, in QAPF diagrams (Streckeisen 1976, 1979). The qualitative analysis of magnetic anomalies in the Colombian Caribbean margin delineated the main anomalies using magnetic intensity maps reducedto-pole (IMTRP. Graterol, 2006. Figure 2a, and Mantilla-Pimiento, 2007. Figure 2B). The latter allowed the expansion of anomalies coverage towards the Chimichagua Platform (ChPl) area.

Major, minor and trace elements (MMT) geochemical characterization was performed in three well core samples (Cicuco-22, Remolino-1 and Sitio Nuevo-1) and in three outcrop samples (Table 1, Figure 1). ICPOES (inductively coupled plasma optical emission spectrometry, equipment type: Perkin Elmer 2100 DV) and ICP-MS (inductively coupled plasma mass spectrometry, equipment type: Perkin Elmer ELAN 6000) were used as analytical techniques. In addition, $\mathrm{U}-\mathrm{Pb}$ geochronological dating using the LA-ICP-MS technique was performed in zircons from four (4) LMV core samples from wells (Coral-9, Cicuco-22, Sitio Nuevo-1 wells) and one in SJeA (30325; Table 1S). Samples from localities 30110, 30311, 30313, and 30314 of the SjeA were also included in the

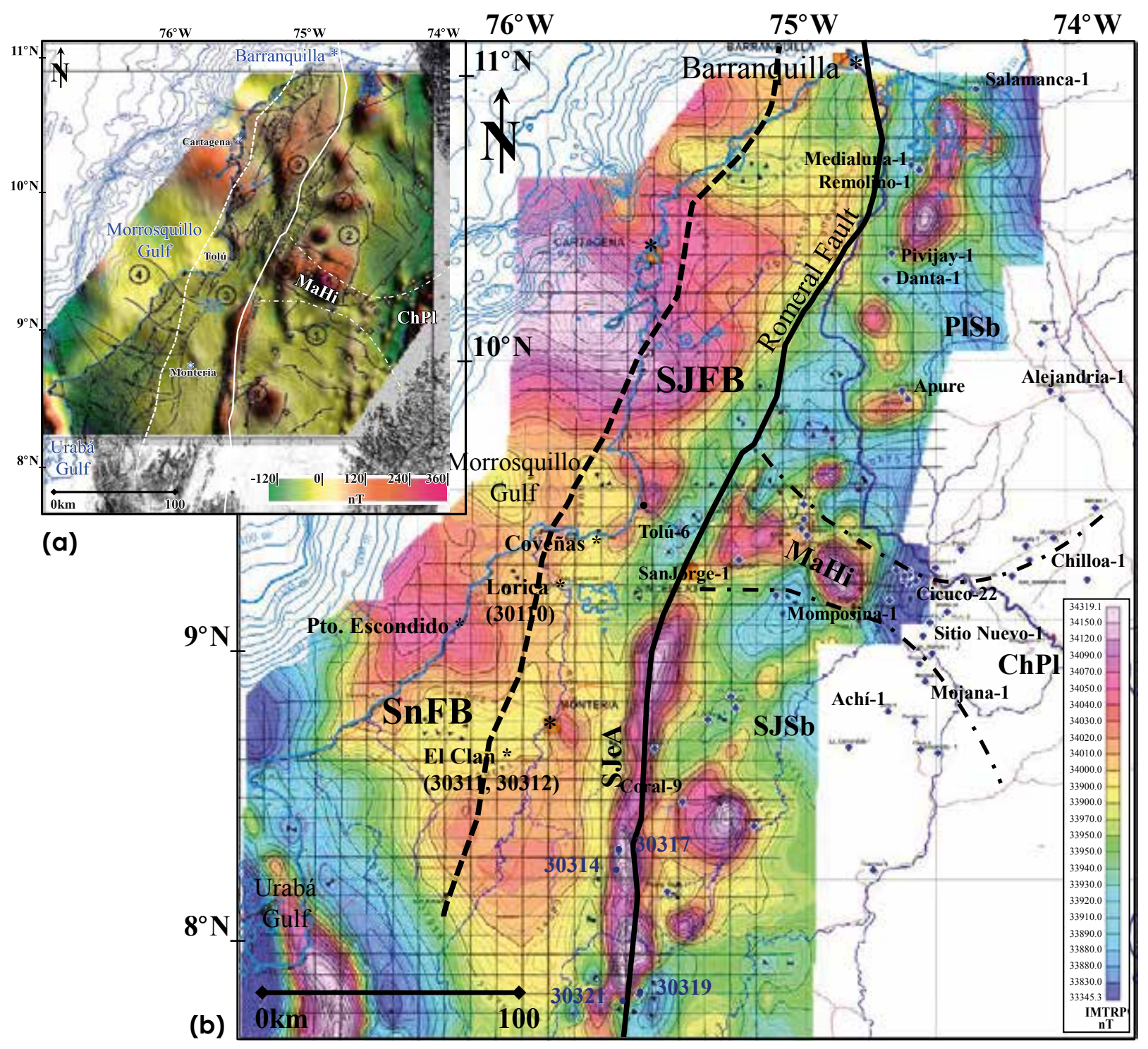

Figure 2. IMTRP magnetic anomalies map (magnetic reduced-to-pole) in the versions of a) Graterol (2006), and b) Mantilla-Pimiento (2007); with the location of wells and analyzed outcrops (Table 1). SnFB: Sinú Fold Belt; SJFB: San Jacinto Fold Belt; SJeA: San Jerónimo Anticline; SJA: San Jacinto Anticline; LA: Luruaco Anticline; LMV: Lower Magdalena Valley; SJsB: San Jorge sub-Basin; PlsB: Plato sub-Basin; MaHi: Magangué High; ChPl: Chimichagua Platform; SNSM: Sierra Nevada de Santa Marta; SLR: San Lucas Range; GP: Guajira Peninsula. 
geochronological analyses, nevertheless zircons were absent and no dating was obtained. The details related to the zircon separation process and the corresponding isotopic analysis was summarized in Chang, Vervoort, McClelland, \& Knaack, (2006). Finally, petrographic, geochemical and geochronological information was integrated to the qualitative interpretation of magnetic anomalies maps.

\section{RESULTS}

\section{Distribution of basement magnetic anomalies}

Our qualitative interpretation of the magnetic anomalies reduced-to-pole (IMTRP) from Graterol (2006; Figure 2a) and Mantilla-Pimiento (2007; Figure $2 b$ ), shows a differentiation in the intensity of magnetic anomalies along the Romeral Fault. This limit separates a scenario of generally-high magnetic anomalies towards the SJFB and SnFB, contrasting with a wide spectrum in intensity of magnetic anomalies towards the LMV (Figure 2a). In SJFB and SnFB, the magnetometric values are estimated between 33950 and $34320 \mathrm{nT}$ (according to Graterol's scale, 2006) including high magnetic anomalies (34020-34320 nT) distributed widely along the SnFB shoreline (i.e. Cartagena and Puerto Escondido), or with a larger extension but following the direction of the Romeral Fault (at $\sim 30 \mathrm{~km}$ to the W) in SJFB (i.e. Montería, Lorica, Coveñas and Tolú). The main SJFB magnetic anomaly is identified on the Romeral Fault at SJeA, where it has a clear elongated shape $(\sim 150 \mathrm{~km}$ long and $<25 \mathrm{~km}$ wide $)$, in a $\mathrm{N} 10^{\circ} \mathrm{E}$ trend over the area connected to the $\mathrm{SJsB}$ (Figure 2a). Towards the LMV, the complete spectrum of magnetic anomalies is included, from low to high levels, with magnetic anomalies easily delineated and interpreted as medium- and high-intensity (33960 and $34320 \mathrm{nT}$ ), opposed to an environment of predominantly low magnetic anomalies (33345-33960 nT; Figure 2a). The main LMV magnetic anomaly is located in the MaHi, where the San Jorge-1, San Pedro-1 and Cicucos wells are located. The anomaly has a $\mathrm{N} 60^{\circ} \mathrm{W}$ trend, $\sim 70 \mathrm{~km}$ long and 40-25 km wide, and separates the basin into two depocenters. To the NE, PlsB includes small anomalies of high magnetic intensity along the Romeral Fault ( $<25 \mathrm{~km}$ to the SE; Apure-1, Pivijay-1, Remolino-1 and Salamanca-1 wells) (Figure 2a); and to the SW, SJsB has some larger anomalies of high intensity facing SJeA, where Coral-9 and Ayapel-1 wells are located (Figure 2a).

\section{Petrography}

The petrographic analysis of some LMV well samples allowed the identification of igneous rocks (plutonic and volcanic) in nine of the analyzed wells (Table 1, Figure 1). The felsic plutonic rocks were classified as granodiorite in PlsB (Alejandría-1 well) and monzogranite in the $\mathrm{ChPl}$ and SJsB (Chilloa-1 and Coral-9 wells, respectively) (Figures 2 and 3a). The monzogranite from the Chilloa-1 well has an inequigranular allotriomorphic texture with local perthitic textures (Figure 4a). The mafic plutonic rocks were classified as quartz diorites-diorites in PlsB

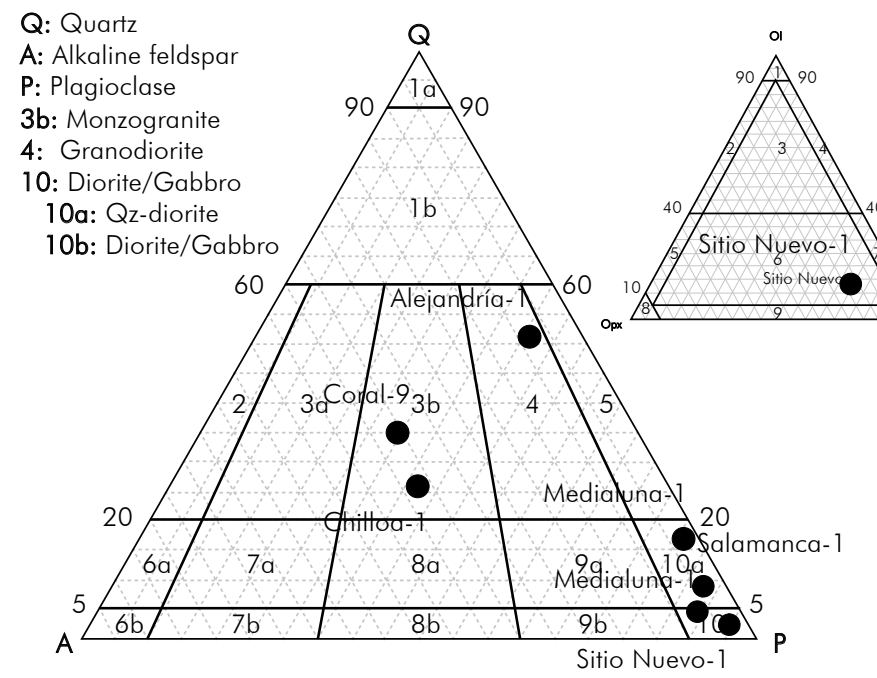

(a)

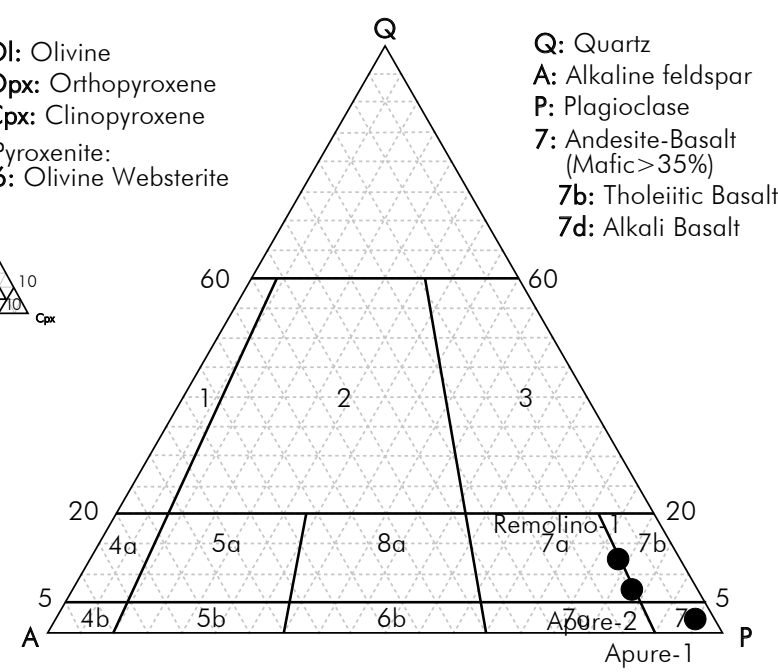

(b)

Figure 3. a) Streckeisen (1976) classification diagrams for plutonic, felsic, mafic and ultramafic rocks from wells: Alejandría-1, Coral-9 and Chilloa-1, Salamanca-1, Medialuna-1, (Streckeisen, 1979) and Sitio Nuevo-1. b) Streckeisen (1979) classification diagram of volcanic rocks from the Remolino-1, Apure-1 and Apure-2 wells. 


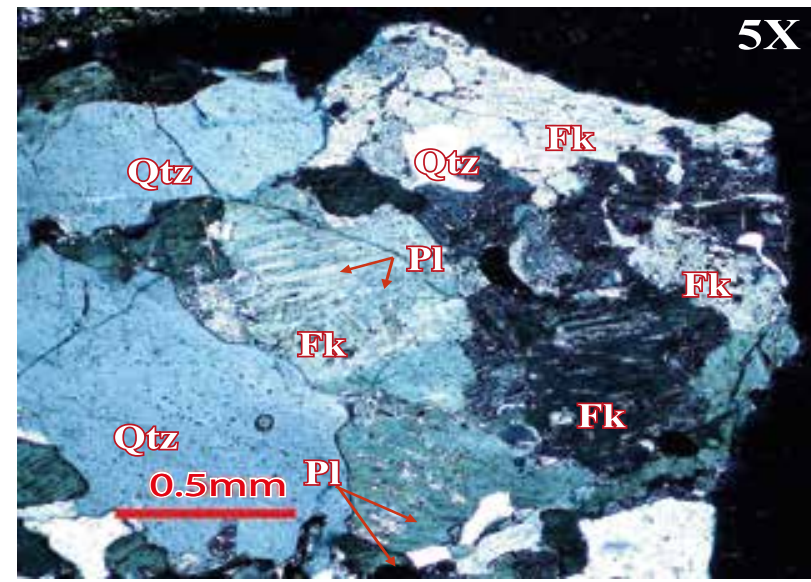

(a)

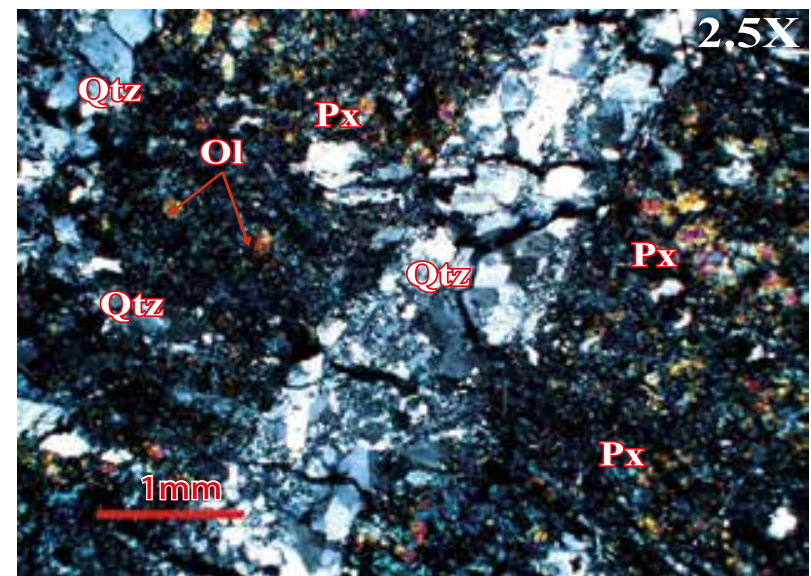

(c)

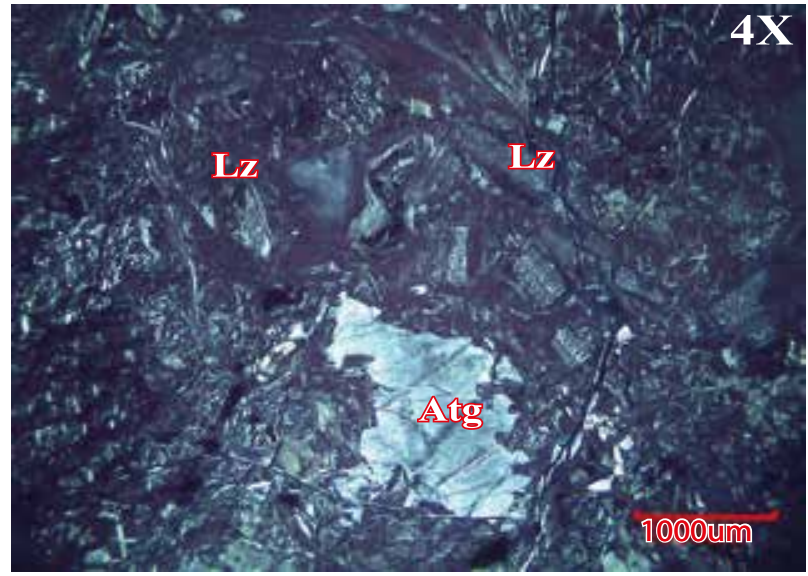

(e)

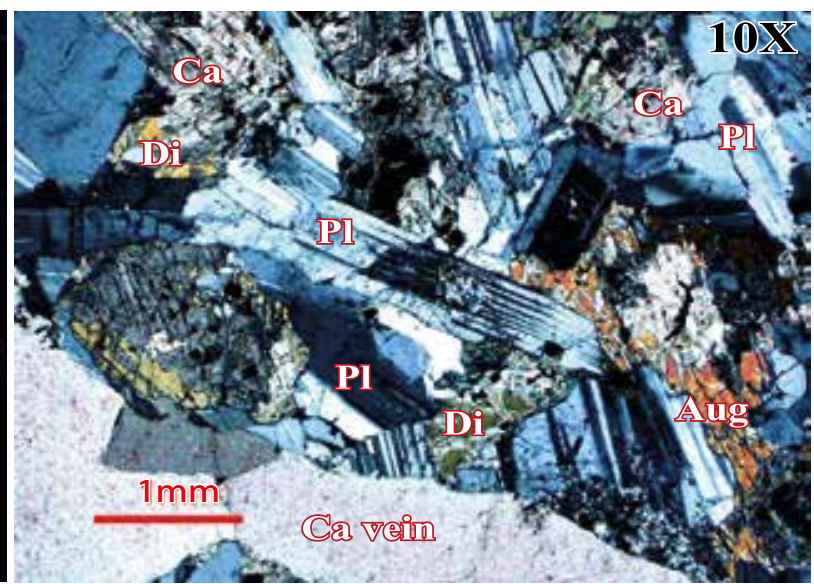

(b)

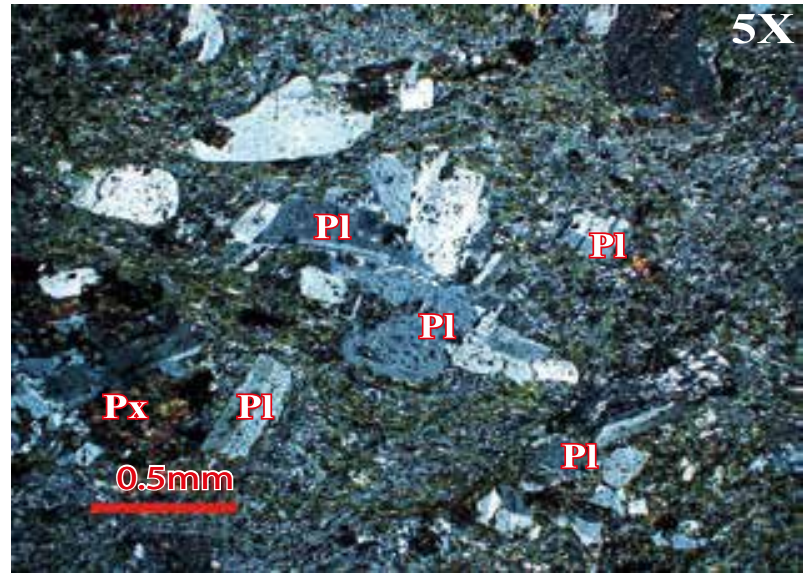

(d)

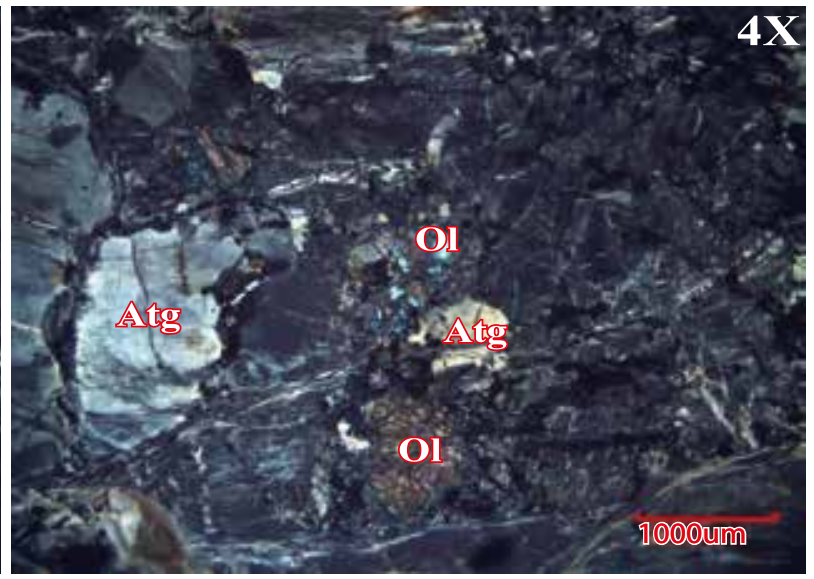

(f)

Figure 4. a) Monzogranite fragments in the Chilloa- 1 well cuttings, with inequigranular allotriomorphic texture of anhedral quartz crystals (Qtz), potassic feldspar (FK) and plagioclase (PI); showing a local perthitic texture of PI lamellas within the FK and incipient development of sericite as a product of hydrothermal alteration. b) Gabbro from the Sitio Nuevo-1 well with plagioclase crystals (PI), diopside (Di) and augite (Aug), altered to calcite (Ca) c) Pyroxenite from the Sitio Nuevo-1 well with pyroxenes (Px) and olivine (OI) and epigenetic quartz veinlets (Qtz). d) Andesite from the Remolino-1 well with glomeroporfidic texture with plagioclase phenocrysts (PI) with a Pl-Qtz-Px matrix. e) Serpentinite with pseudomorphic texture with slight preservation of the texture features of $\mathrm{Ol}$ and Px which have been strongly altered to lizardite (Lz) and antigorite (Atg) from the original Planeta Rica Peridotite. f) Serpentinite with pseudomorphic texture still preserving relict olivine crystals (Ol) altered to antigorite (Atg), coming from the original peridotite from the basic and ultrabasic Uré Complex 
(Medialuna-1 and Salamanca-1 wells) and as gabbropyroxenite in MaHi (Sitio Nuevo-1 well) (Figures 2, 4b and $4 \mathrm{c})$. On the other hand, the volcanic rocks identified in LMV were classified as andesites (Remolino-1 and Apure-2 wells) (Figure 3b) and calc-alkaline basalts (Apure-1 well) in the PlsB (Figure 2). The andesites show a glomeroporfidic texture (Figure 4d); while the basalts have an amigdaloid texture formed by vacuoles filled with chlorite (towards the borders).

An analysis was also performed on outcropping serpentinized samples in SJeA. The first ones correspond to Planeta Rica Peridotites (stations 30314 and 30317; Figure 2), which have a pseudomorphic texture (olivine and pyroxene-like texture) with minerals such as lizardite $(91.3 \%)$, chrysolite $(1.2 \%)$ and antigorite $(1.1 \%)$ (Figure $4 \mathrm{e})$. Estimated age from those peridotites is Upper Cretaceous according to Dueñas \& DuqueCaro (1981). A second sample cluster correspond to the Uré basic and ultrabasic Complex (stations 30318 and 30319; Figure 2), which present a pseudomorphic texture and relicts (olivine crystals) with minerals such as lizardite $(78.5 \%)$, antigorite $(5.6 \%)$ and chrysolite $(5.2 \%)$ (Figure $4 \mathrm{f})$. Estimated age of these basic and ultrabasic complex is Lower Cretaceous according Zapata \& Cossio (2001). Finally, in the Tarazá area (station 30325), the composition of tonalite from the Puquí Complex (Lower Triassic; Carmona \& Pimentel, 2002) was classified as follows: plagioclase (41-36\%), quartz (40-35\%), biotite (10-6\%), moscovite (6-4\%), potassic feldspar (4.8-4.1\%) and opaque minerals $(4.4 \%)$ filling interstitial spaces, with inequigranular hipiodiomorphic texture, and myrmekite-like local texture.

\section{Geochemistry}

Annex 1 contains detailed results of chemical composition of core samples from the LMV, on the basis of different relationships between the main oxides, and between these and trace elements and Rare Earths study. The samples from Sitio Nuevo-1, Remolino-1 and Cicuco-22 wells are projected toward the field of sub-alkaline magmatic rocks (Figure 5a), and are geochemically classified as follows: Basaltic-Andesite (Sitio Nuevo-1 well) and Rhyolite (Cicuco-22 well) in $\mathrm{MaHi}$, and Dacites in PlsB (Remolino-1 well) (Figure $5 \mathrm{~b})$. The results allow establishing a link between the igneous lithologies analyzed from the Remolino-1, Cicuco-22 and Sitio Nuevo-1 wells, and subduction settings (Figures $5 \mathrm{c}-\mathrm{f}$ ). The $\mathrm{Ba} / \mathrm{La}$ ratio in these igneous rocks (Remolino-1=110,21; Cicuco-22=80,90 and Sitio Nuevo-1 $=47,84$ ), allows to suggest more specifically that these lithologies were formed in an arc settings (threshold values $>20$ ). The $\mathrm{La} / \mathrm{Yb}$ vs. $\mathrm{Sc} / \mathrm{Ni}$ ratios allow to propose that the magmatism generated by the PlsB igneous rocks (Remolino-1 well), took place in a thinned continental crust, while those found in MaHi (Cicuco-22 well), seem to be more related to a thicker continental crust (Andes type).

Regarding the samples collected in the SJeA, it is evident that the classification of igneous materials, according to their chemical composition, is clearly inconsistent with the rock lithology (Annex 2). Such is the case of the basalt (station 30313) and serpentinite (station 30314) from the Planeta Rica area, which reach $\mathrm{SiO}_{2}$ values of $71.60 \%$ and $63.99 \%$ in weight, which would project these rocks towards the field of acidic rocks. Even though contamination is not discarded, their high $\mathrm{SiO}_{2}$ content may also suggest the presence of quartz veinlets in the sample, or possible alterations caused by silicification. More specifically, the serpentinite sample (station 30314) from the Planeta Rica area shows a high $\mathrm{MgO}$ content (Annex 2), which is characteristic of peridotitic materials (ultramafic, primitive rocks). This rock shows serpentinization of its mafic minerals and might be related to materials characteristic of the lithospheric mantle upperparts (due to the presence of plagioclase), which may have experienced hydration processes (serpentinization) as a response to the fluids seepage leakage derived from dehydration (fluid release) of the subducted materials (located under the peridotitic materials).

On the other hand, the basalt analysis from Planeta Rica area (station 30313) and tonalite from Tarazá area (station 30325), allows to conclude that these materials are related to supra-subduction magmatic arcs (Annex 2), which have a different maturity degree, being basalt (station 30313) originated from a slightly more primitive magmatic arc, as compared to tonalite (station 30325).

\section{Geochronology}

In this study, four geochronological datings were performed (Table 2). In the MaHi, a gabbro from Sitio Nuevo-1 well (core) was dated; its analytical data and the $\mathrm{U}-\mathrm{Pb}$ isotopic relationships determined in different growth areas of the zircons analyzed with the LA- 


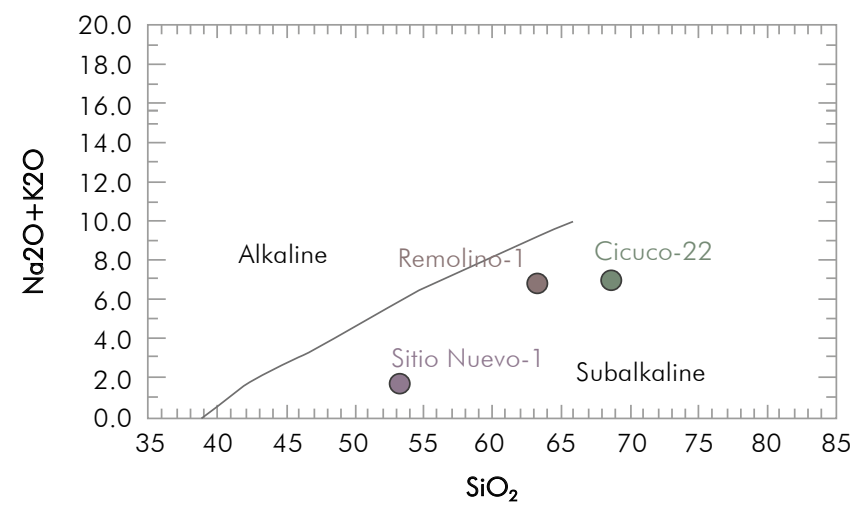

(a)

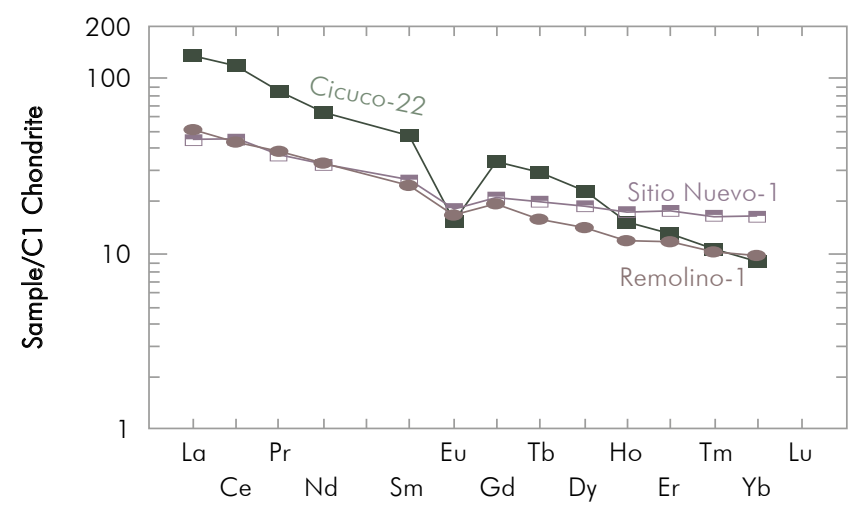

(c)

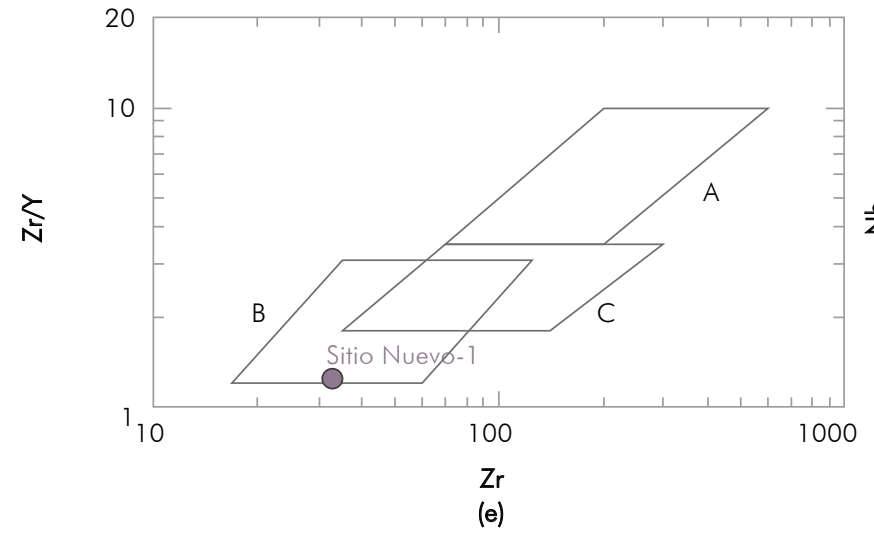

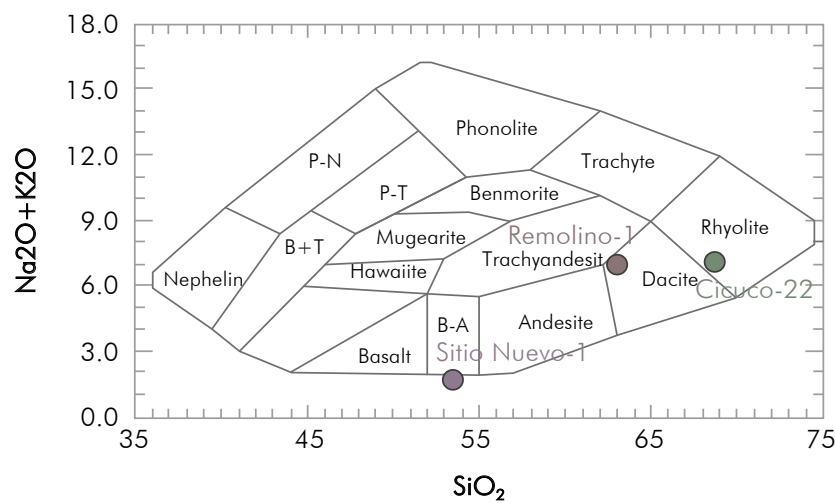

(b)

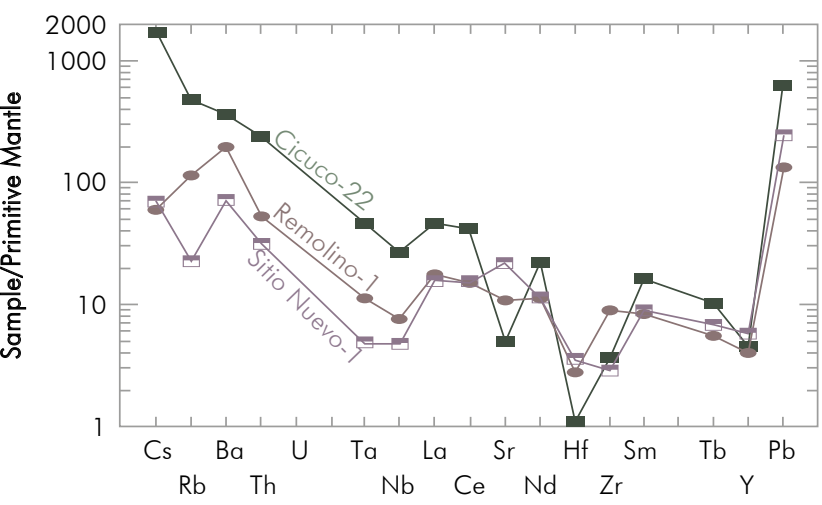

(d)

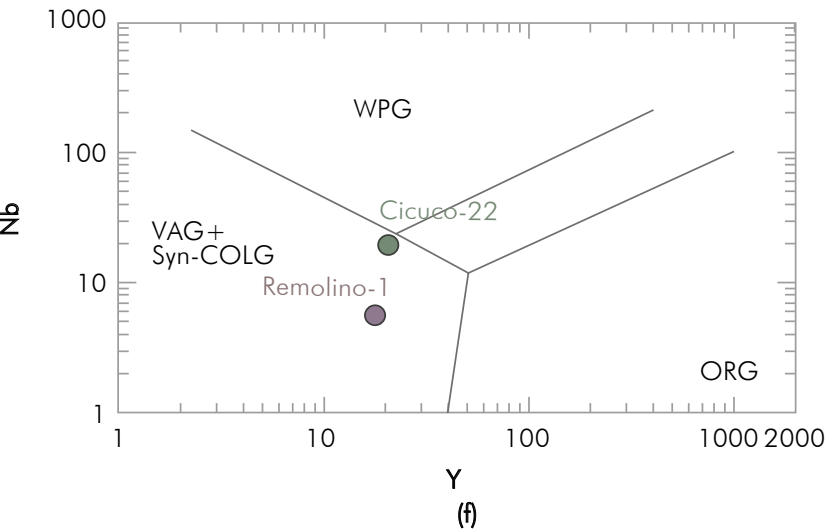

Figure 5. Geochemical diagrams for the classification of samples from the Sitio Nuevo-1, Cicuco-22 and Remolino-1 wells. a) Diagram for discrimination of magma series according to Irvine \& Baragar (1971); b) TAS classification (Cox et al., 1979); c) Rare Earths Pattern, normalized to Chondrite C1; d) Trace elements, normalized to the Primitive Mantle; e) Diagram for discrimination of the tectonic setting by Pearce \& Norry (1979). Extrusive analogous of the plutonic rock herein analyzed. f) $\mathrm{Nb}$ vs. Y diagram for the discrimination of the tectonic setting for magma emplacement (Pearce et al., 1984).

ICP-MS technique (34 analyses performed), indicate the presence of a single group showing an age of 300 \pm 1.3 Myr (Figure 6a; Annex 3). Also in the MaHi, a syenogranite from the Cicuco-22 well (core) was dated; its analytical data and the $\mathrm{U}-\mathrm{Pb}$ isotopic relationships (37 analyses performed) indicate the presence of six age groups, even though the largest group has an age range related to the syenogranite crystallization, of $84.6 \pm 0.6 \mathrm{Myr}(68 \%, 25$ data points) (Figure 6b;
Annex 3). In SJsB, monzogranite from the Coral-9 well (cuttings) was dated; its analytical data and the $\mathrm{U}-\mathrm{Pb}$ isotopic relationships (38 analyses performed) indicate the presence of eight age groups: the most recent group shows an age range for monzogranite of $74.5 \pm 1.9 \mathrm{Myr}(21 \%)$, and the second group shows an age of $232 \pm 3.2 \mathrm{Myr}$ (55\%) (Figure 6c; Annex 3). This second age group is considered as inherited and derived from zircons coming from Triassic rocks. To 
Table 2. Distribution of wells and outcrops by: structural domain, location, lithology, estimated intensity of magnetic anomaly (IMTRP by Graterol, 2006) and U-Pb age. (ID: Indeterminate; *: Petrographic description taken from Cerón et al., 2007; †: U/Pb dating taken from Montes et al., 2010; \#: Ar-Ar dating taken from Lara et al., 2013).

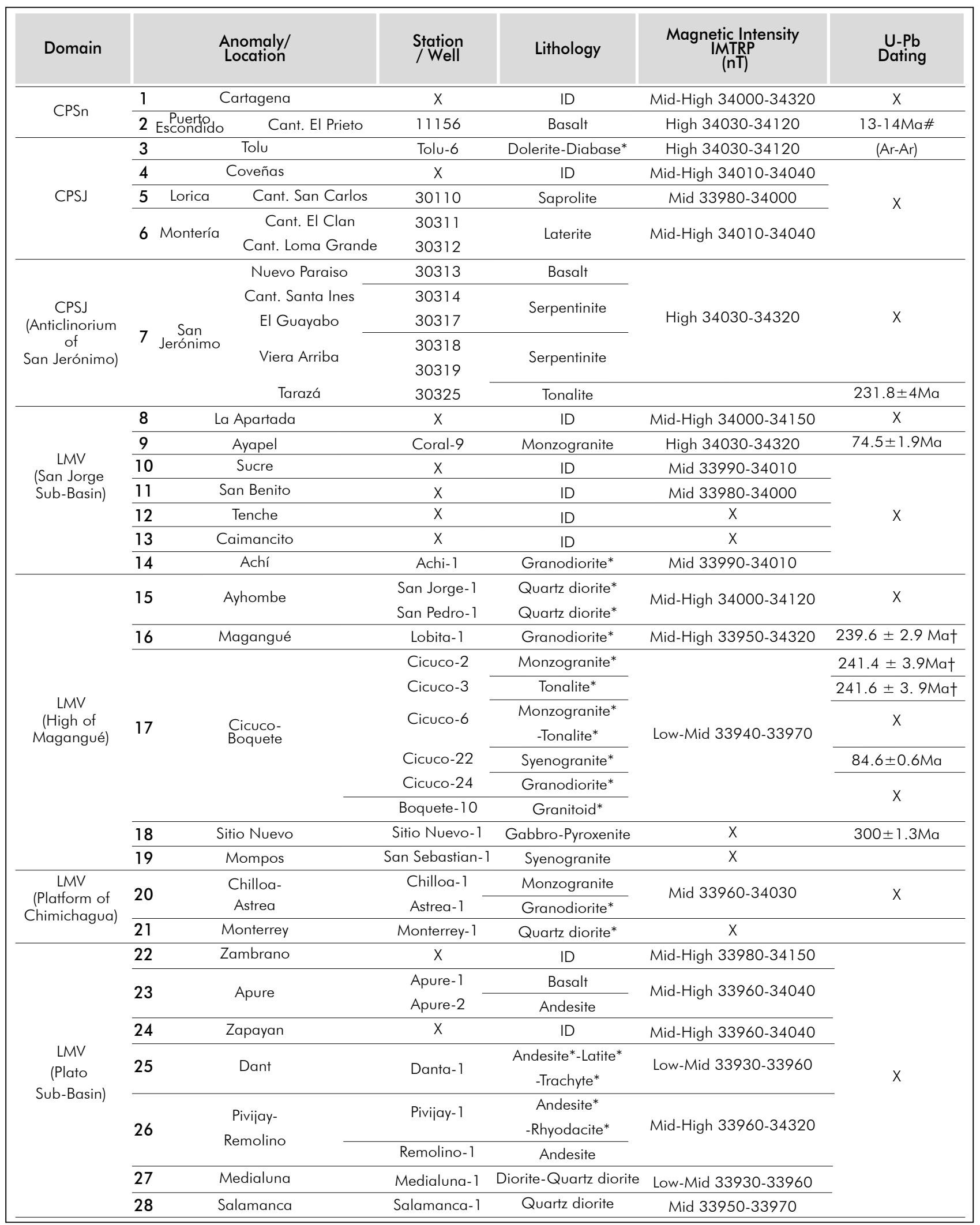



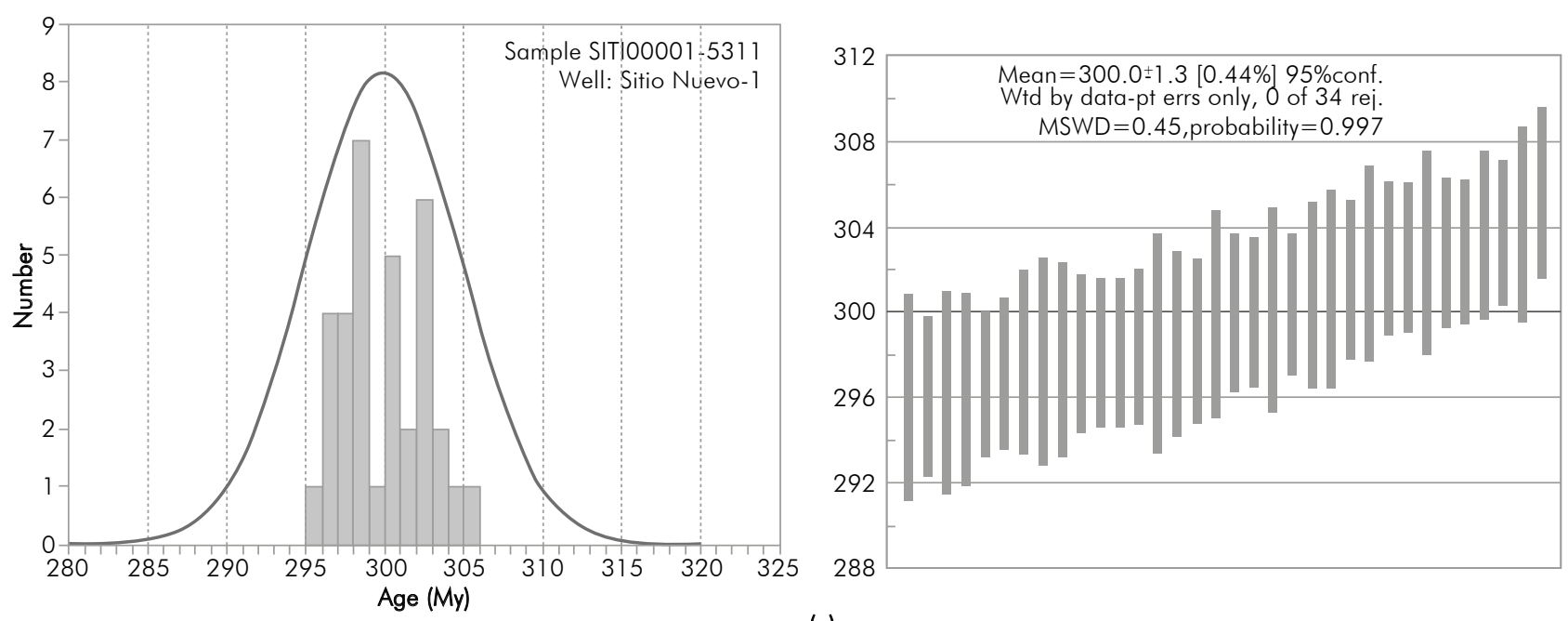

(a)
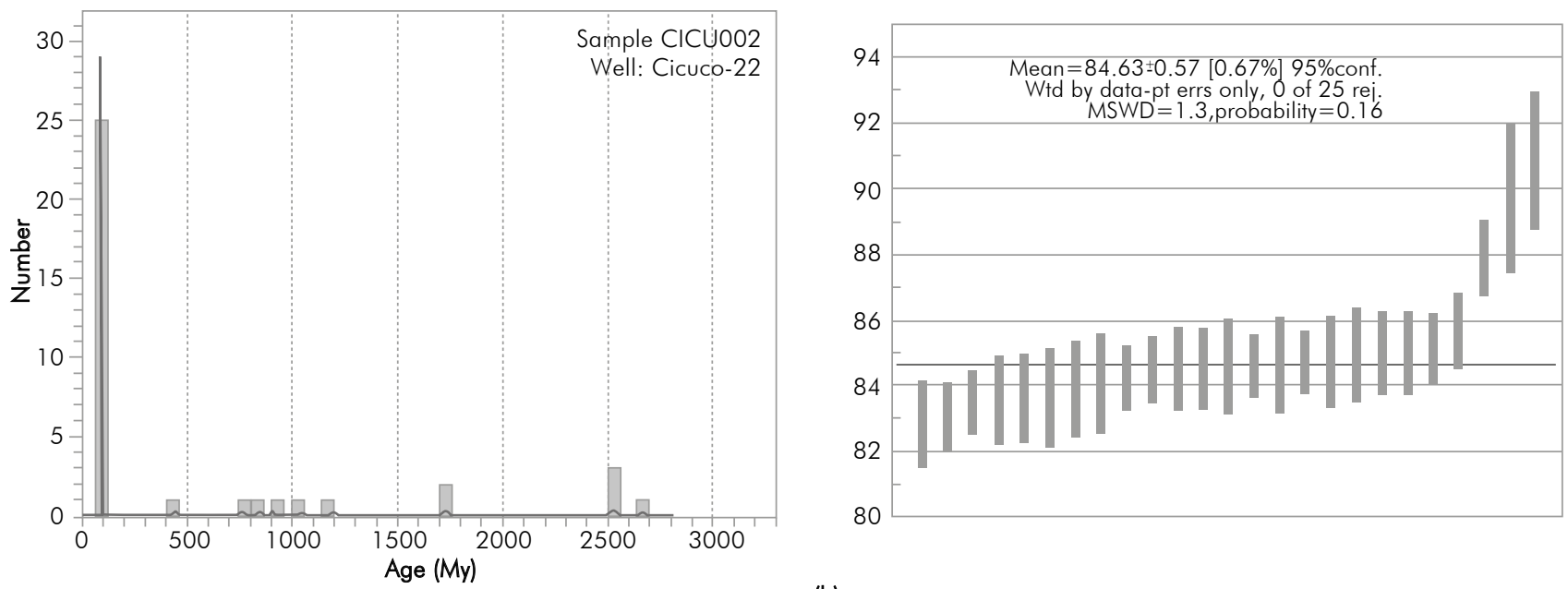

(b)
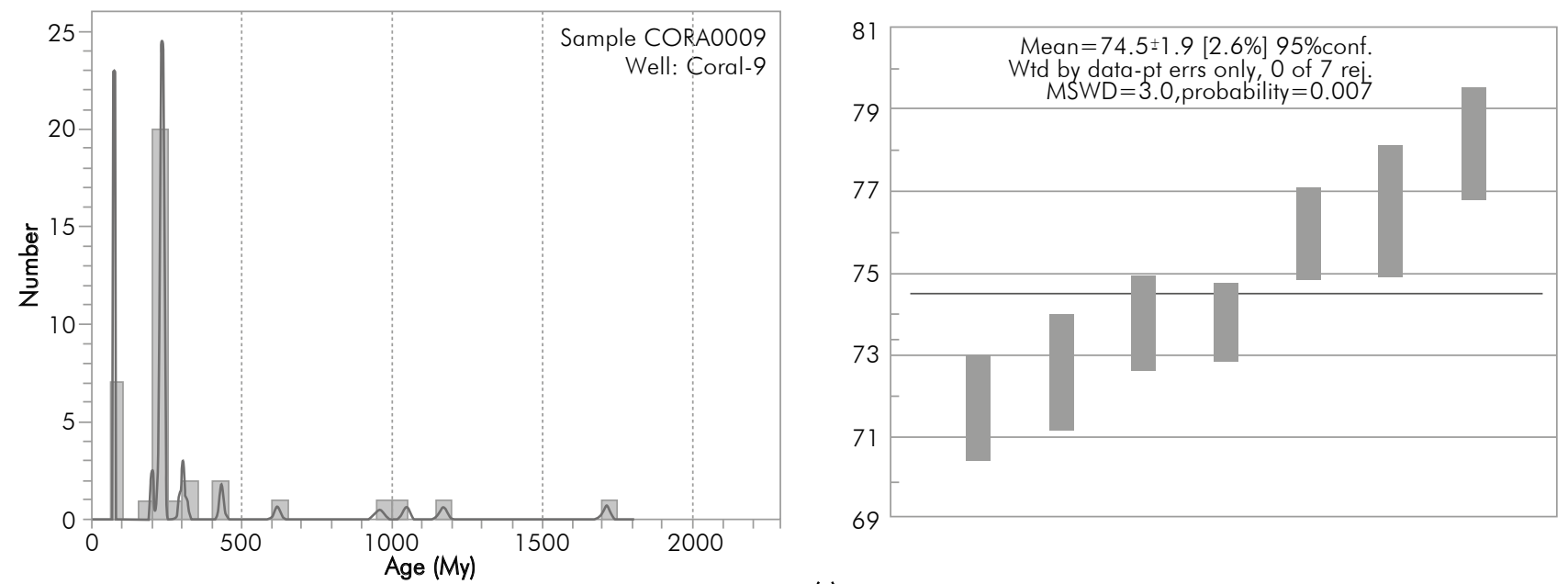

(c)

Figure 6. Age probability distribution for the zircons sampled in the Sitio Nuevo-1 a), Cicuco-22 b), Coral-9 c) wells and station 30325 . At the right of each histogram, the possible ages of basements and a summary of every age of the zircons calculated using the $206 \mathrm{~Pb} / 238 \mathrm{U}$ ratio are illustrated, including the errors such as $2 \mathrm{~s}$ uncertainties (see discussion in text). 

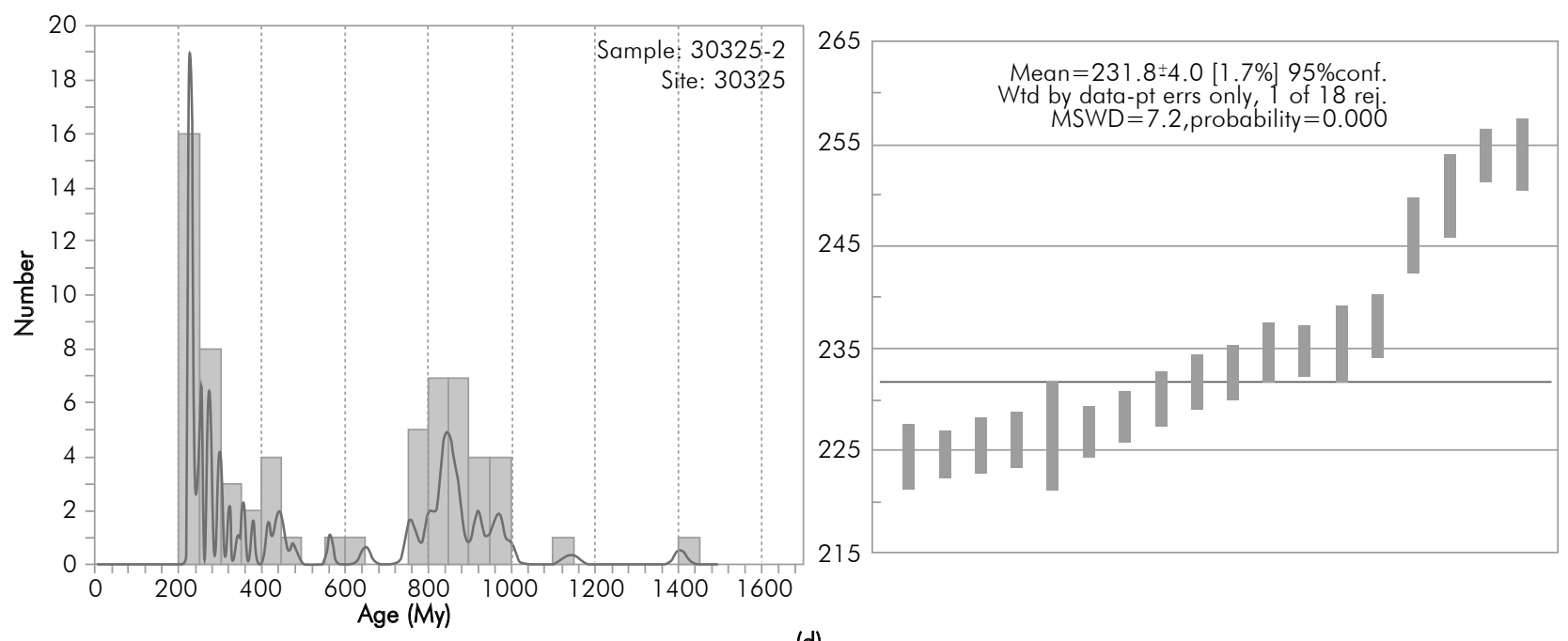

(d)

Figure 6. (continuation) Age probability distribution for the zircons sampled in the Sitio Nuevo-1 a), Cicuco-22 b), Coral-9 c) wells and station 30325. At the right of each histogram, the possible ages of basements and a summary of every age of the zircons calculated using the $206 \mathrm{~Pb} / 238 \mathrm{U}$ ratio are illustrated, including the errors such as 2 s uncertainties (see discussion in text).

the South, the tonalite from the Puquí Complex in the Cordillera Central foothills (station 30325) was dated; the $\mathrm{U}-\mathrm{Pb}$ isotopic relationships (65 analyses performed) indicate the presence of at least six age groups: the most recent group (52\%, 34 data points) shows an age range for tonalite of $231.8 \pm 4 \mathrm{Myr}$, while the second group (42\%, 27 data points) shows an age of 850 My (Figure 6d; Annex 3).

\section{DISCUSSION}

\section{Correlation between Magnetic anomalies and basement lithologies}

The combination of lithological composition and qualitative interpretation of magnetic anomalies (IMTRP), allowed generating a basement lithological occurrences map for the South Caribbean Colombian margin (Figure 7, Table 2). On this map, two highintensity magnetic anomalies were identified in SnFB: (1) the undetermined anomaly to the North of Cartagena, which extends towards SJFB, and, (2) the anomaly to the South, corresponding to basalts emplaced in Middle Miocene rocks from the Puerto Escondido area (station 11156, Table 2, Figure 2a) (Lara et al., 2013) (Figure 7). The prolongation of these anomalies towards the offshore is limited by the IMTRP maps extension.

In the SJFB, five high intensity magnetic anomalies were identified, which mainly correspond to igneous bodies of mafic and ultramafic composition (Table 2). They are identified from North to South as follows: (3) high intensity anomaly from the Tolú-6 well diabase, which can be extended to the SE toward the (4) Coveñas area (Figure 7). To the SSW, the medium to high intensity anomalies correspond to the saprolitized peridotites from (5) Lorica (San Carlos quarry) and the lateritized peridotites from (6) Montería (El Clan and Loma Grande quarries). In both areas, peridotites outcrop in imbricate thrusts underlying the Upper Cretaceous Cansona Formation (Annex 4). To the East, the highintensity anomaly of (7) San Jerónimo, corresponds to serpentinites (metamorphized peridotites), identified in the El Guayabo, Santa Inés Quarry and Viera Arriba area (Table 2). In addition, basalts were identified in Late Cretaceous rocks (Cansona Formation) and Paleocene (San Cayetano Formation), in the Nuevo Paraíso and Quebrada Nueva areas (station 30321; Table 1) (Figures 2 and 7).

To the SW of the LMV, 14 anomalies (medium to high intensity) are identified and distributed as follows: seven anomalies in SJsB, five anomalies in $\mathrm{MaHi}$ and two anomalies in $\mathrm{ChPl}$, which correspond to felsic and intermediate intrusive rocks (syenogranite, monzogranite, granodiorite and quartz diorite), in addition to mafic intrusive rocks (gabbro-pyroxenite; Sitio Nuevo-1 well) (Table 2; Figure 7). On the contrary, to the NE of LMV, in PlsB, seven magnetic anomalies are identified (medium to high intensity) 


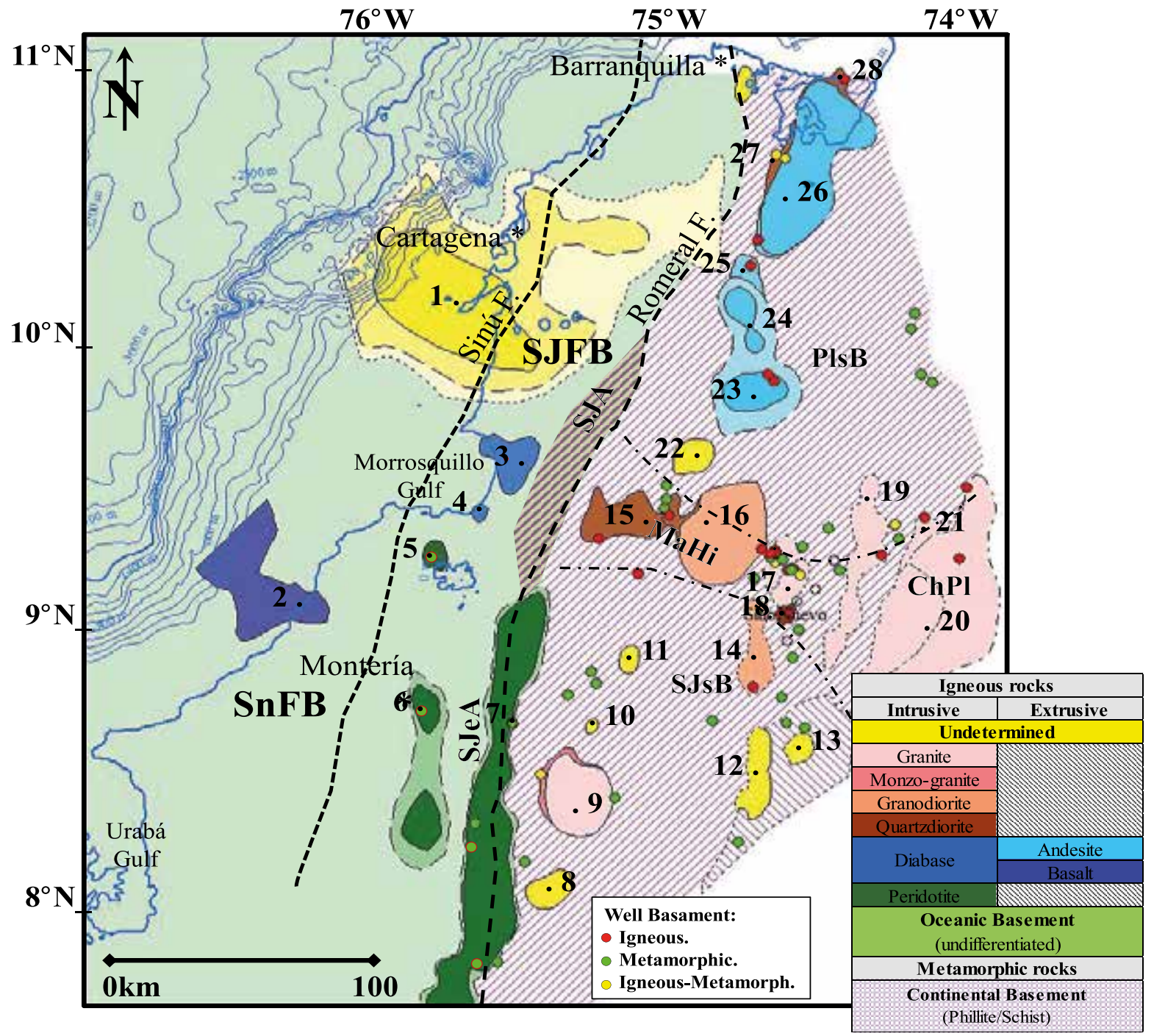

Figure 7. Map of basement lithological occurrences defined from the correlation of well composition data, outcrops and magnetic anomalies (listed in Table 2). SnFB: Sinú Fold Belt; SJFB: San Jacinto Fold Belt; SJeA: San Jerónimo Anticline; SJA: San Jacinto Anticline; SJsB: San Jorge sub-Basin; PlsB: Plato sub-Basin; MaHi: Magangué High; ChPl: Chimichagua Platform.

and correlated to extrusive felsic to mafic rocks (trachyte, andesite, rhyodacite and basalt) and some anomalies corresponding to intermediate-composition intrusive rocks (diorite-quartz diorite; Medialuna-1 and Salamanca-1 wells) (Table 2; Figure 7). On the map, the Romeral Fault seems to define the surface contact between the oceanic-like mafic rocks, outcroping to the NW, and the intrusive and extrusive, felsic to intermediate rocks, intruded in a continental basement to the SE (Duque-Caro, 1979; Flinch, 2003; Cerón et al., 2007; Mantilla-Pimiento, 2007) (Figure 7).

\section{Tectonic evolution}

According to the $\mathrm{U}-\mathrm{Pb}$ datings (Table 2), there is a Permo-Triassic (300 - 235 Myr) magmatic pulse, recorded in granitoids (Lobita-1: $239.6 \pm 2.9 \mathrm{Myr}$,
Cicuco-2 and -3: 241.4 \pm 3.9 Myr; Montes et al. 2010), and gabbros (Sitio Nuevo-1: $300 \pm 1.3 \mathrm{Myr}$, Figure 6a) identified at the MaHi. The gabbro's presence in a continental crust stands out since they are of metaluminic nature (type-I magma), which corresponds to a suprasubduction setting (Figure 5e). As emplacement mechanism it is proposed the occurrence of cortical fissures. Other locations where magmatic crystallization has been recorded from the Late Permian to the Early Triassic are: the SNSM $(288.1 \pm 4.5 \mathrm{Myr}$ and $276.5 \pm$ 5.1 Myr; Cardona et al., 2010), the North of the CC (248 \pm 17 Myr; Ordoñez and Pimentel, 2001a, b), and the Puquí Complex (Tarazá, station 30325), which tonalite sample exhibits an age of $231.8 \pm 4 \mathrm{Myr}$ (Figure 6d; Annex 3). This first tectono-thermal event occur in the frame of the Pangaea's collision and Allaganian 
Mountains formation during the Permian (Woodward, 1957 in: Secor, Snoke, \& Dallmeter, 1986); as well as the post-Alleganian event marking the rifting onset between Gondwana-Laurentia during the Early-Mid Triassic in the LMV basement.

A second, Late Cretaceous, magmatic pulse, is recorded in different LMV locations. In the MaHi, a syenogranite of peraluminic nature (metaluminic magma fractionation or cortical contamination), and characteristic of a thick continental crust, generated in a subduction setting (Figure 5f) yields an age of 84.6 $\pm 0.6 \mathrm{Myr}$ (Cicuco-22 well; Figure 6b). In the SJsB, a monzogranite yields an age of $74.5 \pm 1.9 \mathrm{Myr}$ (Coral-9 well; Figure 6c), in addition to an inherited age from the first Triassic magmatic pulse ( $232 \pm 3.2 \mathrm{Myr}$; Figure $6 \mathrm{c})$. This evidence suggests the existence of a magmatic arc of Late Cretaceous age in the LMV basement, defined in this paper as Magangué Magmatic Arc. Its existence is based upon the igneous bodies occurrence along the Romeral Fault (Figure 7), among which Permian mafic (Sitio Nuevo-1) and Triassic felsic sources (Montes et al. 2010) are identified in the MaHi; as well as Late Cretaceous sources (Cicuco-22, Coral-9 wells) in the $\mathrm{MaHi}$ and SJsB (Table 2), in addition to the presence of intermediate intrusive-extrusive bodies in the PlsB (Table 2).

The ages (84-72 Myr) and geochemical characteristics of the magmatic bodies in the LMV are similar to those reported in a group of outcropping igneous rocks in the Cordillera Central (CC), as those from the Antioquia Batholith (E.g. Restrepo-Moreno et al., 2007a, b; Ibañez, Tassinari, \& Jaramillo, 2007; Ibañez, Jaramillo, \& Valencia, 2008; Ibañez, Vinasco, Cardona, Valencia, \& Weber, 2010); as well as to other small intrusive bodies, including the Sonsón and Segovia batholiths, distributed in the North segment of CC (Ordóñez \& Pimentel, 2001a, b; Restrepo-Moreno, Foster, \& Kamenov, 2007a), b; Ordóñez et al., 2008; Villagómez et al., 2011). Therefore, this study proposes the continental basement continuity from the Tahami Terrane (sensu Restrepo \& Toussant, 1988) up to the LMV (Figure 8), with the existence of at least two important magmatic arcs, developed within the same context of suprasubduction and as a response to the interaction between the Farallones or the ancient proto-Caribbean plates and the South American plate (E.g. Aspden et al., 1987; Ordoñez et al., 2008; Pindell \& Kennan, 2009; RestrepoMoreno et al., 2009; Villagómez et al., 2011).
Even though the Magangué Magmatic Arc reflects a Late Cretaceous active margin, it does not necessarily imply its juxtaposition with an oceanic Magmatic Arc, represented by the Planeta Rica basalts (station 30313). At the moment of its formation, the oceanic basement must have been in a different location and subsequently must have been accretioned to the continental plate, during the Late Cretaceous/Paleogene as evidenced by the saprolitized and lateritized peridotite folded and thrusted below the Cansona Formation (Annex 4).

Additionally, establishing the petrogenetic and chronological relationship of these igneous bodies, of mafic and ultramafic composition, as reported in the Planeta Rica, Montería and Lorica areas, with other allochtonous fragments from the Caribbean Plate attached to the northern margin of South America is a difficult task. To the north of the LMV, in the SNSM, Cardona et al. (2010) have reported a magmatic event, associated to subduction ( $90-65 \mathrm{Myr}$ ), which generated the crystallization of an orthogneiss and intra-plate volcanic-arc granitoids formed by melting of metabasalt sources $(50-68 \mathrm{Myr})$. In the Guajira Peninsula, Weber et al. (2009) associate the Cabo de la Vela Mafic Complex (and possibly the Etpana Formation) with back-arc settings, occurring over on oceanic crust over the Benioff Zone, which then experienced a transition toward an intraoceanic island arc. Furthermore, to the East of Colombia, in the Paraguaná Peninsula, Los Monjes Island, Curaçao Island, Gran Roque Island, mafic composition lithologies are displayed (Santamaría \& Schubert, 1974; Toro et al., 2014). These rocks represent a tholeitic series, characteristic of oceanic ridges and, by extension, of sea floor in general. Further to the East, in the Aves Ridge and Lesser Antilles areas, there is basaltic and doleritic lithologies to which an intraoceanic-arc origin was attributed (Neill, Kerr, Hastie, Stanek, \& Millar, 2011; Santamaría \& Schubert, 1974; Bouysse et al., 1990). However, the uncertainty regarding the formation age of serpentinites and basalts from the Planeta Rica area, as well as genetic processes difference, make it impossible to establish a link between these rocks and what are considered relicts of the Great Caribbean Arc.

\section{CONCLUSIONS}

- The described and delimited lithologies from the LMV basement, as well as new well data ages reported here, support a basement correlation to the lithologies and 


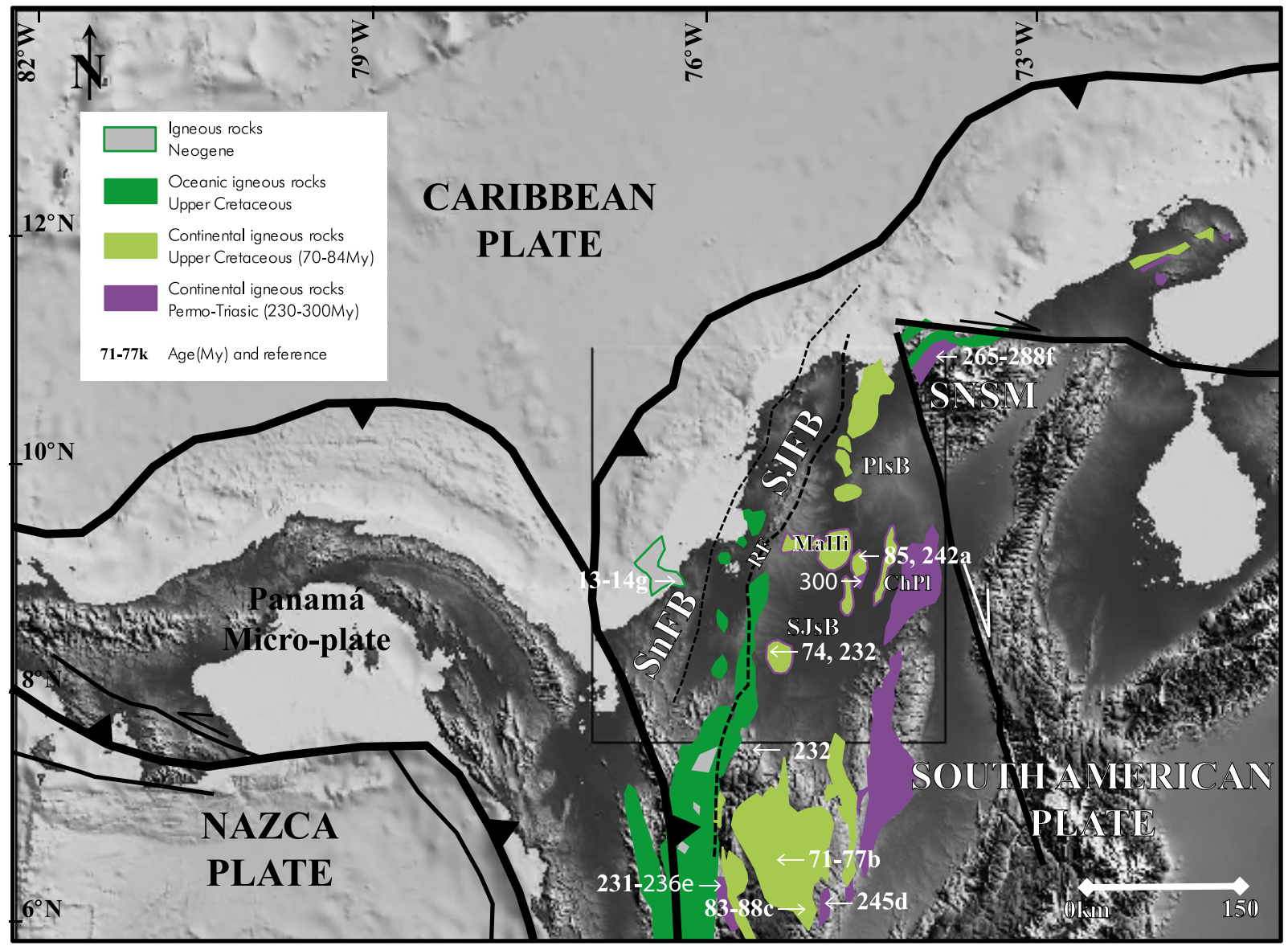

Figure 8. Distribution of the Magangue Magnetic Arc in the LMV to the North and continuity of intrusive bodies of the two magmatic pulses identified in the LMV (Permo-Triassic and Late Cretaceous) (modified from Ayala et al., 2012). Ages from Montes et al. (2010); Restrepo et al. (2007); Ibañez et al. (2007); Ibañez et al. (2008); Rodriguez-Jimenez (2010); Cardona et al., (2010); and Lara et al. (2013). SnFB: Sinú Fold Belt; SJFB: San Jacinto Fold Belt; PlsB: Plato sub-Basin; MaHi: Magangué High; Ch: Chimichagua Platform; SJsB: San Jorge sub-Basin; SNSM: Sierra Nevada de Santa Marta.

ages identified in the CC, being the LMV basement the northern extension of the Tahami Terrane from the CC.

- The Magangué Magmatic Arc of the LMV has a Late Cretaceous age ( $84-70 \mathrm{Myr})$ and consist of felsic to intermediate igneous bodies (Coral-9 and Cicuco-22 wells), which intrude an older tectono-thermal event of Permo-Triassic age (300-235 Myr), also identified in the MaHi (Sitio Nuevo-1 well and wells dated by Montes et al., 2010) and in SJsB (inherited zircons in the Coral-9 well).

- The existence of the Magangué Magmatic Arc and its close tectono-temporal relationship with an important group of igneous rocks outcropping in CC (i.e. Antioquia, Sonsón, Segovia, and other batholiths) supports the establishment of an Active Continental
Margin for the Late Cretaceous, implying the onset of subduction of the Farallon or proto-Caribbean plates underlying the North of the South American Plate, with the intrusion of felsic to intermediate magmas (some peraluminic) in the LMV continental crust.

- In the aforementioned tectonic setting, the differences between the Magangué Magmatic Arc and the Antioquia Batholith would be related to the WadatiBenioff zone depth, and its corresponding implications: a progressive decrease in volatiles contribution toward the mantle wedge (as the subducted plate became deeper), and the subsequent reduction of the mantle wedge partial fusion percentage, among other aspects. The knowledge of the relationship between the two aforementioned magmatic arcs has an evident implication in the mineral deposits exploration and the evolution of Colombian sedimentary basins. 


\section{ACKNOWLEDGEMENTS}

This research was funded by Instituto Colombiano del Petróleo ICP-Ecopetrol S.A on the framework of the project "Estudio de rocas pre-Neógenas en el Caribe Colombiano a través de cronoestratigrafía, geoquímica, análisis de proveniencia y termocronología”. We thank Gabriel Mendoza, Carlos Acuña, Edward Salazar, Gyna Rincón, and some other Colombian geoscientist for sample collecting, field observations and beneficial discussions. Additional support during the data synthesis phase of this research was provided by Mauricio Pinzón and Davis Guerra, whom organized this valuable information in a very practical georeferenced database. L. F. Peña and staff of Geologic Samples Laboratory at the Instituto Colombiano del Petróleo are also acknowledged for their help with sample preparation. We are thankful to the anonymous reviewers for their comments and suggestions that allowed us to improve and clarify the manuscript.

\section{REFERENCES}

Aspden, J. A., McCourt, W., \& Brook, M. (1987). Geochemical control of subduction-related magmatism: the Mesozoic and Cenozoic plutonic history of Western Colombia. J. Geol. Soc. Lond., 144, 893-905.

Aubouin, J., Baltuck, M., Arnott, R. J., Bourgois, J., Filewiez, M., Helm, R., Kvenvolden, K. A., Lienert, B., Mc Donald, T., Mc Dougall 1. K., Ogawa, Y., Taylor, E., \& Winsborough, B. (1982). Leg 84 of the Deep Sea Drilling Project, subduction without accretion, Middle America Trench off Guatemala. Nature, 297, 458-460.

Ayala R. C., Bayona G., Cardona A., Ojeda C., Montenegro O. C., Montes C., Valencia V., \& Jaramillo C. (2012). The paleogene synorogenic succession in the northwestern Maracaibo block: Tracking intraplate uplifts and changes in sediment delivery systems. J. South Am. Earth Sci., 39, 93111. DOI: http://dx.doi.org/10.1016/j.jsames.2012.04.005.

Bailey, J. C. (1981). Geochemical criteria for a refined tectonic discrimination of orogenic andesites. Chem. Geol., 32 (14), 139-154.

Ball, M. M., Harrison, C. G. A., \& Supko, P. R. (1969). Atlantic opening and the origin of the Caribbean. Nature, 223, 167-168.
Barrero, D., Pardo, A., Vargas, C., \& Martínez, J. F. (2007). Colombian Sedimentary Basins: Nomenclature, Boundaries and Petroleum Geology, a New Proposal, 92p.

Bayona G., Cardona A., Jaramillo C., Mora A., Montes C., Valencia V., Ayala C., Montenegro O., \& Ibañez, M. (2012). Early Paleogene magmatism in the northern Andes: Insights on the effects of Oceanic Plateau-continent convergence. Earth Planet. Sci. Lett., 331-332, 97-111.

Bouysse, P., Westercamp, D., \& Andrieff, P. (1990), The Lesser Antilles island arc, Proc. Ocean Drill. Program Sci. Results, $110,29-44$.

Burke, K. (1988). Tectonic evolution of the Caribbean. Ann. Rev. Earth Planet. Sci., 16, 210-230. DOI: 10.1146/ annurev.ea.16.050188.001221

Burke, K., Fox, P. J., \& Sengor, A. M. C. (1978). Buoyant ocean floor and the evolution of the Caribbean. J. Geophys. Res., 83, 3949-3954.

Cardona, A., Ruiz, J., Valencia, V., Garzón, A., Ojeda, G., \& Weber, M. (2010). Tectonomagmatic setting and provenance of the Santa Marta Schists, northern Colombia: Insights on the growth and approach of Cretaceous Caribbean oceanic terranes to the South American continent. J. South Am. Earth Sci., , 29, 784-804.

Carmona, O., \& Pimentel, M. (2002). Rb-Sr and Sm-Nd isotopic of the Puquí Complex, Colombian Andes. J. South Am. Earth Sci., 15, 173-182.

Cediel, F., Shaw, R. P., \& Caceres, C. (2003). Tectonic assembly of the Northern Andean Block. In: Bartolini, C., Buffler, R. T., Blickwede, J. (Ed). The Circum-Gulf of Mexico and the Caribbean: Hydrocarbon Habitats, Basin Formation, and Plate Tectonics. AAPG Memoir, 79, 815-848.

Cerón, J. F., Kellogg, J., \& Ojeda G. (2007). Basement configuration of the northwestern South America-Caribbean margin from recent geophysical data. CTyF - Ciencia, Tecnología y Futuro, 3 (3), 25-49.

Chang, Z., Vervoort, J. D., McClelland, W. C., \& Knaack, C. (2006). U-Pb dating of zircon by LA-ICP-MS. Geochem. Geophys. Geosyst., 7, 1-14.

Cochrane, R., Spikings, R., Gerdes, A., Winkler, W., Ulianov, A., Mora, A., \& Chiaradia, M. (2014). Distinguishing between in-situ and accretionary growth of continents along active margins. Lithos, 202-203, 382-394. 
Condie, K. C., \& Sloan, R. E. (1997). Origin and evolution of earth: Principles of historical geology. New Jersey: Prentice-Hall.

Donnelly, T. W. (1985). Mesozoic and Cenozoic plate evolution of the Caribbean region. En: Stehli, F. G. \& Webb, S. D. (Ed). The Great American Biotic Interchange. New York, Springer, 89-121.

Donnelly, T.W. (1994). The Caribbean Cretaceous basalt association: A vast igneous province that includes the Nicoya Complex of Costa Rica, in: Seyfried, H. \& Hellman, W. (Ed). Geology of and evolving island arc: The Isthmus of southern Nicaragua, Costa Rica and western Panamá. Stuttgart, Alemania, Profile (Band 7), Institut fur Geologie un Paleontologie, 17-45.

Driscoll, N. W. \& Diebold, J. B. (1999). Tectonic and Stratigraphic development of the Eastern Caribbean: New Constraints from Multichannel seismic data. En: Mann, P. (Ed). Caribbean Basins. Sedimentary Basins of the World 4. Amsterdam. Elsevier. Science B.V., 591-626.

Dueñas, H. \& Duque-Caro, H. (1981). Geología del Cuadrángulo F-8, Planeta Rica. Boletin Geológico INGEOMINAS, 24 (1), 1-35.

Duque-Caro, H., (1979). Major structural elements and evolution of northwestern Colombia. In: Watkins, J. S., Montadert, L., \& Dickerson, P. W. (Ed). Geological and geophysical investigations of continental margins. AAPG Memoir, 29, 329-351.

Duque-Caro, H. (1984). Structural style, diapirism and accretionary episodes of the Sinú-San Jacinto terrane southwestern Caribbean borderland. GSA, 162, 303-316.

Escalona, A., \& Mann, P. (2011). Tectonics, basin subsidence mechanisms, and paleogeography of the CaribbeanSouth American plate boundary zone. Mari Petrol. Geol., 28 (1), 8-39. DOI: http://dx.doi.org/10.1016/j. marpetgeo.2010.01.016.

Flinch, J. F. (2003). Structural Evolution of the Sinú-Lower Magdalena Area (Northern Colombia). In: Bartolini, C., Buffler, R. T., \& Blickwede, J. (Ed). The Circum-Gulf of Mexico and the Caribbean: Hydrocarbon habitats, basin formation, and plate tectonics. AAPG Memoir, 79, 776-796.

Graterol, V. (2006). Levantamiento aerogravimétrico y aeromagnético. Adquisición, procesamiento e interpretación de datos de aeromagnetogravimetría en el litoral Caribe. Bogotá: ANH.
Guzmán, G. (2007). Stratigraphy and sedimentary environment and implications in the Plato Basin and the San Jacinto belt Northwestern Colombia. Ph.D. Thesis. Université de Liege. Liege 487pp.

Ibañez, M., Vinasco, C., Cardona, A., Valencia, V. \& Weber, M. (2010). Permian-Triassic orogenesis in the northern andes: a record of arc magmatism, accretion, anatexis and relaxation of a continental terrane in the Proto-Andes in the wake of Pangaea. Geological Society of America, Annual meeting, 197.

Ibañez, M., Tassinari, C. \& Jaramillo, J. (2007). U-Pb Zircon Ages of the "Antioquian Batholith": Geochronological Constraints of Late Cretaceous Magmatism in the Central Andes of Colombia. XI Congreso Colombiano de Geología. Bucaramanga, Colombia.

Ibañez, M., Jaramillo, J. \& Valencia, V. (2008). U-Th/Pb Zircon Geochronology by multicollector LA-ICP-MS of the Samaná Gneiss: A Middle Triassic Syn-Tectonic body in the Central Andes of Colombia, related to the latter stages of Pangaea assembly. VI South American Symposium on Isotope Geology. San Carlos de Bariloche, Argentina.

ICP. (2000). Evaluación regional integrada de la cuenca del Valle Inferior del Magdalena. Piedecuesta: ECOPETROLICP. 10 tomos.

INGEOMINAS. (1997). Atlas geológico digital de Colombia. Ministerio de Minas y Energía, República de Colombia, Sheets $1,3,4$, and 6 .

James, K. H. (2006). Arguments for and against the Pacific origin of the Caribbean Plate: discussion, finding for an inter-American origin. Geol. Acta, 4 (1-2), 279-302. DOI: 10.1344/105.000000370.

Kammer, A. (1993). Las Fallas de Romeral y su relación con la tectónica de la Cordillera Central. Geologia Colombiana, $18,27-46$.

Lara, M., Cardona, A., Monsalve, G., Yarce, J., Montes, C., Valencia, V., Weber, M., De La Parra, F., Espitia, D., \& M. López-Martínez. (2013). Middle Miocene near trench volcanism in northern Colombia: A record of slab tearing due to the simultaneous subduction of the Caribbean Plate under South and Central America?. J. South Am. Earth Sci., 45, 24-41. DOI: http://dx.doi.org/10.1016/j. jsames.2012.12.006.

Laverde, F. (2000). The Caribbean Basin of Colombia, a composite Cenozoic Accretionary Wedge with UnderExplored Hydrocarbon Potential. VII Simposio Bolivariano de Exploración Petrolera en Cuencas Subandinas. Caracas, Venezuela. 
Mann, P., Calais, E., Ruegg, J. C., DeMets, C., Jansma, P., \& Mattioli, G. (2002). Oblique collision in the northeastern Caribbean from GPS measurements and geological observations, Tectonics, 21 (6), 1057. DOI: 10.1029/2001TC001304.

Mantilla-Pimiento, A.M. (2007). Crustal structure of the southwestern Colombian Caribbean margin. Geological interpretation of geophysical data. Ph.D. Thesis Insitut für Geowissenschaften. Friedrich-Schiller-Universität Jena. Jena, Alemania, 121 pp.

Meschede, M, \& Frisch, W. (1998). A plate-tectonic model for the Mesozoic and Early cenozoic history of the Caribbean Plate. Tectonophysics, 296 (3-4), 269-291. http://dx.doi. org/10.1016/S0040-1951(98)00157-7.

Montes, C., Guzman, G., Bayona, G., Cardona, A., Valencia, V., \& Jaramillo, C. (2010). Clockwise rotation of the Santa Marta massif and simultaneous Paleogene to Neogene deformation of the Plato-San Jorge and Cesar-Ranchería basins. J. South Am. Earth Sci., 29, 832-848. DOI: http:// dx.doi.org/10.1016/j.jsames.2009.07.010.

Neill, I., Kerr, A. C., Hastie, A. R., Stanek, K.-P., \& Millar, I. L. (2011). Origin of the Aves Ridge and Dutch Venezuelan Antilles: interaction of the Cretaceous "Great Arc" and Caribbean-Colombian Oceanic Plateau? J. Geol. Soc. London, 168, 333-347. DOI: 10.1144/0016-76492010-067.

Ordoñez, O., Pimentel, M. \& Laux, J. H. (2008). Edades U-Pb del Batolito Antioqueño. Bol. Ciencias de la Tierra, 22, 125-140.

Ordoñez, O., \& Pimentel, M. M. (2001a). Rb-Sr and Sm-Nd isotopic study of the Puquí complex, Colombian Andes. J. South Am. Earth Sci., 15 (2), 173-182. DOI: 10.1016/ S0895-9811(02)00017-2.

Ordóñez, O., \& Pimentel, M. M (2001b). Consideraciones geocronológicas e isotópicas del Batolito Antioqueño. Rev. Aced. Cienc. Exactas: Fisic. Natural., 25, 27-35.

Pindell, J. L., \& Kennan, L. (2009). Tectonic evolution of the Gulf of Mexico, Caribbean and Northern South America in the mantle reference frame: an update. Geol. Soc. London Special Public., 328, 1-55. DOI: 10.1144/SP328.1.

Pindell, J., Kennan, L., Stanek, K. P., Maresch, W. V., \& Draper, G., (2006). Foundations of Gulf of Mexico and Caribbean evolution: eight controversies resolved. Geol. Acta, 4, 303-341. DOI: 10.1344/105.000000371.
Restrepo-Moreno, S., Foster, D. A., \& Karmenov, G. (2009). Crystallization age and magma source of the Antioqueño and Ovejas Batholiths, Central Cordillera, Colombia; evidence from combined LA-ICP-MS U-Pb dating and Hf-isotope analysis of zircon grains and whole rock geochemistry. Geol. Soc. Am. Abstracts with programs, 41 (7), 222 p.

Pindell, J. L. (1990). Geological arguments suggesting a Pacific origin for the Caribbean Plate. En: Larue, D. K., \& Draper, G. (Ed). Transactions of the 12th Caribbean Geological Conference. Miami Geological Society, St. Croix, 1-4.

Pindell, J. L., Cande, S. C., Pitman Iii, W. C., Rowley, D. B., Dewey, J. F., Labrecque, J., \& Haxby, W. (1988). A platekinematic framework for models of Caribbean evolution. Tectonophysics, 155, 121-138.

Restrepo, J. J., \& Toussant, J. F. (1988). Terranes and continental accretion in the Colombian Andes. Episodes, 11 (3), 189-193.

Restrepo-Moreno, S., Foster, D.A., \& Kamenov, G. (2007a). Formation age and magma sources for the Antioqueño Batholith derived from LA-ICP-MS Uranium-Lead dating and Hafnium-isotope analysis of zircon grains. Geol. Soc. Am., Annual Meeting, Abstracts, 181-28 (Paper).

Restrepo-Moreno, S., Foster, D., \& Kamenov, G. (2007b). Formation age and magma sources for the Antioqueño and Ovejas batholiths derived from $\mathrm{U}-\mathrm{Pb}$ dating and $\mathrm{Hf}$ isotope analysis of zircon grains by LA-ICP-MS. GSA Abstracts with Programs, 39 (6), 493.

Santamaría, F., \& Schubert, C. (1974). Geochemistry and geochronology of the Southern Caribbean-Northern Venezuela plate boundary. Bull. Geol. Soc. Am., 85, (7), 1085-1098. DOI: 10.1130/0016-7606(1974)85<1085:GA GOTS>2.0.CO;2.

Secor, D.T., Snoke, A.W. \& Dallmeter, R.D. (1986). Character of the Alleghanian orogeny in the southern Appalachians: Part III. Regional tectonic relations. GSA Bulletin, 97, 1345-1353.

Streckeisen, A. (1976). To each plutonic rock its proper name. Earth Sience Rev., 12 (1), 1-33. DOI: https://doi. org/10.1016/0012-8252(76)90052-0.

Streckeisen, A., (1979). A classification and nomenclature of volcanic rocks, lamprophyres and melilitic rocks. Recommendations and suggestion of the IUGS on the Systematic of igneous Rocks. Geology, 7, 331-335. 
Sykes, L. R., Mc Cann, W. R. \& Kafka, A. L. (1982). Motion of the Caribbean plate during the last 7 million years and implications for earlier Cenozoic movements. Journal Geophysical Research, 87, 10656-10676.

Taboada, A., Rivera, L., Fuenzalida, A., Cisternas, A., Philip, H. Bijwaard, H., Olaya, J., \& Rivera, C. (2000). Geodynamics of the northern Andes: subductions and intracontinental deformation (Colombia). Tectonics, 19, 787-813.

Toro, L., Gómez, A., \& Moreno, M. (2014). Metagabros de la isla Gran Roque (Venezuela). Geoquímica y petrografía. Ciencias De La Tierra, 38, 1-9.

Ujueta-Lozano G. (2007). Tectónica de bloques, delimitados por lineamientos de dirección NO-SE y NNE-SSO a NE-SO en el Norte y Nordeste de Colombia y en el Noroccidente de Venezuela. Geología Colombiana. 32, 3-20.

Vallejo, C., Spikings, R. A., Luzieux, L., Winkler, W., Chew, D. \& Page, L. (2006). The early interaction between the Caribbean Plateau and the NW South American Plate. Terra Nova, 188 (4), 264-269.

Villagómez, D., Spikings, R., Magna, T., Kammer, A., Winkler, W., \& Beltrán, A., (2011). Geochronology, geochemistry and tectonic evolution of the Western and Central Cordilleras of Colombia. Lithos, 125, 875-896.

Weber, M.B.I., Cardona, A., Paniagua, F., Cordani, U., Sepúlveda, L., \& Wilson, R. (2009). The Cabo de la Vela mafic-ultramafic complex, Northeastern Colombian Caribbean region - a record of multi stage evolution of a Late Cretaceous intra- oceanic arc. En: James, K. H., Lorente, M. A. \& Pindell, J. L. (Ed). Caribbean-South American Plate Interactions. London: GSL Spec. Publ., 394, 549-568.

Weber, M. B. I., Cardona, A., Valencia, V., Altenberger, U., López-Martinez, M., Tobón, M., Zapata, G., \& Concha, A.E. (2011). Geochemistry and Geochronology of the Guajira Eclogites, northern Colombia - evidence of a metamorphosed primitive Cretaceous Caribbean Island-arc. Geologica Acta, 9, 425-443.

Woodward, H.P. (1957). Chronology of Appalachian folding. AAPG Bulletin, 41, 2312-2327.

Wright, J. E. \& Wyld, S. J. (2011). Late Cretaceous subduction initiation on the southern margin of the Caribbean-Colombian oceanic plateau: One great arc of the Caribbean?. Geosphere, 7(2), 468-493.
Xie, X. \& Mann, P. (2014). U-Pb detrital zircon age patterns of Cenozoic clastic sedimentary rocks in Trinidad and its implications. Sedimentary Geology, 307, 7-16.

Yañez, P., Ruiz, J., Patchett, P. J., Ortega-Gutierrez, F. \& Gehrels, G. (1991). Isotopic studies of the Acatlan complex, southern Mexico; implications for Paleozoic North America tectonics. GSA Bulletin, 103, 817-828.

Zapata, G, \& Cossio, U. (2001). Mapa fotogeológico con control de campo de la Plancha 93 Cáceres. Bogota: Ingeominas. 59p.

\section{AUTHORS}

\section{Alejandro Silva Arias \\ Afiliation: ECOPETROL S.A. Instituto Colombiano del Petróleo (ICP) \\ e-mail: alejandro.silva@ecopetrol.com.co}

\section{Liliana Andrea Páez Acuña}

Afiliation: Universidad Industrial de Santander,

Escuela de Geología

e-mail: 1ilipa0812@hotmail.com

\section{Javier Alfonso Tamara Guevara}

Afiliation: University of London, Royal Holloway

e-mail: jatamarag@gmail.com

\section{Pedro David Gómez Gutiérrez}

Afiliation: ECOPETROL S.A. Instituto Colombiano del Petróleo (ICP)

e-mail: pedroda@ecopetrol.com.co

Luis Carlos Mantilla Figueroa

Afiliation: Universidad Industrial de Santander,

Escuela de Geología

e-mail: 1cmantil@uis.edu.co

\section{Sandra Milena Restrepo Acevedo}

Afiliation: ECOPETROL S.A. Instituto Colombiano del Petróleo (ICP)

e-mail: Sandra.Restrepo@ecopetrol.com.co

\section{Victor Valencia}

Afiliation: Washington State University

School of Earth and Enviromental Sciences

e-mail: vicvalencia@gmail.com

Eduardo López Ramos

Afiliation: ECOPETROL S.A.

Gerencia de Exploración Offshore, Colombia

e-mail: Eduardo.Lopezra@ecopetrol.com.co

\section{Daniel Andrés Rincón Martínez}

Afiliation: ECOPETROL S.A. Instituto Colombiano del Petróleo (ICP)

e-mail: daniel.rincon@ecopetrol.com.co 


\section{ANNEX 1.}

\section{Correlation between Magnetic anomalies and basement lithologies}

Table A.1 shows the general differences in the geochemical results for igneous lithologies studied in the LMV. From 'Sigma Index' $\left(\mathrm{K}_{2} \mathrm{O}+\mathrm{Na}_{2} \mathrm{O}\right.$ vs. $\mathrm{SiO}_{2}$ ratio; Irvine and Baragar, 1971) we can interpret that samples from the Sitio Nuevo-1, Remolino-1, and Cicuco-22 wells are projected towards the field of subalkaline magmatic rocks (Figure 5a); and according to the Cox et al. diagram (1979; Figure 5b) they are geochemically classified as follows: Basaltic Andesites (Sitio Nuevo-1 well) and Rhyolites (Cicuco-22 well) located in the MaHi and Dacites from the PlsB (Remolino-1 well). Additionally, the $\mathrm{Na}_{2} \mathrm{O} / \mathrm{Al}_{2} \mathrm{O} 3$ vs.
$\mathrm{K}_{2} \mathrm{O} / \mathrm{Al}_{2} \mathrm{O}_{3}$ relationship (in molar values; Davies and Whitehead, 2006) allows to establish that the PlsB's andesite (Remolino-1 well: 0.43 vs. 0.28 ) and the MaHi's syenogranite (Cicuco-22 well: 0.3 vs. 0.36 ) have not experienced significant hydrothermal or supergene alteration (meaning near the potassic-biotite plagioclase-feldspar line). Furthermore, according to the Alumina saturation index (Shand Index or ASI; Maniar and Piccoli, 1989) the andesite sample (Remolino-1 well) is projected towards the field of metaluminic rocks characteristic of type-I magmas (Chappell and White, 1992), as well as the gabbro-pyroxenite from the MaHi (Sitio Nuevo-1 well). On the other hand, the syenogranite found in the MaHi (Cicuco-22 well) is projected towards the field of peraluminic rocks, possibly suggesting a fractionation process of metaluminic magmas or a cortical contamination process.

Table A1. Total rock geochemistry data from core samples, collected from different wells drilled in the Lower Magdalena Valley (LMV).

\begin{tabular}{|c|c|c|c|}
\hline Well & REMOLINO-1 & CICUCO-22 & SITIO NUEVO-1 \\
\hline Depth & $\begin{array}{c}(6410-6420 \mathrm{ft} / \\
1953.8-1956.8 \mathrm{~m})\end{array}$ & $\begin{array}{c}(8227-8233 \mathrm{ft} / \\
2507.6-2509.4 \mathrm{~m})\end{array}$ & $\begin{array}{l}(5311.42 \mathrm{ft} / \\
1618.9 \mathrm{~m})\end{array}$ \\
\hline Age & Indeterminate & Late Cretaceous( $84 \mathrm{Ma})$ & $\begin{array}{l}\text { Carboniferous-Permian } \\
\text { ( } 300 \mathrm{Ma})\end{array}$ \\
\hline Rock type & Andesite (core) & Granodiorite (core) & Gabbro (core) \\
\hline \multicolumn{4}{|c|}{ Major elements (\%) } \\
\hline $\mathrm{SiO}_{2}$ & 63.09 & 68.63 & 53.33 \\
\hline $\mathrm{Al} 2 \mathrm{O}_{3}$ & 12.94 & 13.73 & 15.88 \\
\hline $\mathrm{Fe} 2 \mathrm{O}_{3}$ & 5.92 & 2.92 & 12.17 \\
\hline $\mathrm{MgO}$ & 1.12 & 0.54 & 2.07 \\
\hline $\mathrm{CaO}$ & 2.59 & 0.80 & 5.52 \\
\hline $\mathrm{Na} 2 \mathrm{O}$ & 3.42 & 2.46 & 1.02 \\
\hline $\mathrm{K} 2 \mathrm{O}$ & 3.34 & 4.60 & 0.64 \\
\hline $\mathrm{TiO}_{2}$ & 0.56 & 0.26 & 2.01 \\
\hline $\mathrm{P}_{2} \mathrm{O}_{5}$ & 0.25 & 0.19 & 0.11 \\
\hline $\mathrm{MnO}$ & 0.12 & 0.02 & 0.19 \\
\hline $\mathrm{Cr}(\mathrm{ppm})$ & 12.32 & 10.00 & 11.58 \\
\hline $\mathrm{Ni}(\mathrm{ppm})$ & 6.94 & 4.44 & 57.62 \\
\hline Sc (ppm) & 11.16 & 7.88 & 42.90 \\
\hline LOI (\%): $1000^{\circ} \mathrm{C}$ & 0.90 & 2.83 & 5.92 \\
\hline Total sum of oxides & 93.36 & 94.15 & 92.94 \\
\hline \multicolumn{4}{|c|}{ Minor and trace elements (ppm) } \\
\hline $\mathrm{Ba}$ & 1338.00 & 2556.00 & 510.00 \\
\hline Co & 13.93 & 3.62 & 123.00 \\
\hline Cs & 0.47 & 13.25 & 0.56 \\
\hline $\mathrm{Ga}$ & 18.38 & 22.97 & 20.68 \\
\hline $\mathrm{Hf}$ & 0.84 & 0.34 & 1.07 \\
\hline $\mathrm{Nb}$ & 5.39 & 19.52 & 3.34 \\
\hline
\end{tabular}


Table A1. (Continuation) Total rock geochemistry data from core samples, collected from different wells drilled in the Lower Magdalena Valley (LMV).

\begin{tabular}{|c|c|c|c|}
\hline Well & REMOLINO-1 & CICUCO-22 & SITIO NUEVO-1 \\
\hline Depth & $\begin{array}{c}(6410-6420 \mathrm{ft} / \\
1953.8-1956.8 \mathrm{~m})\end{array}$ & $\begin{array}{c}(8227-8233 \mathrm{ft} / \\
2507.6-2509.4 \mathrm{~m})\end{array}$ & $\begin{array}{l}(5311.42 \mathrm{ft} / \\
1618.9 \mathrm{~m})\end{array}$ \\
\hline Age & Indeterminate & Late Cretaceous( $84 \mathrm{Ma})$ & $\begin{array}{c}\text { Carboniferous-Permian } \\
\text { ( } 300 \mathrm{Ma})\end{array}$ \\
\hline Rock type & Andesite (core) & Granodiorite (core) & Gabbro (core) \\
\hline \multicolumn{4}{|c|}{ Major elements (\%) } \\
\hline $\mathrm{Rb}$ & 72.15 & 296.00 & 14.58 \\
\hline $\mathrm{Sr}$ & 225.00 & 103.00 & 464.00 \\
\hline $\mathrm{Ta}$ & 0.45 & 1.88 & 0.19 \\
\hline Th & 4.47 & 20.44 & 2.62 \\
\hline U & 1.47 & 4.40 & 3.41 \\
\hline V & 128.00 & 9.37 & 610.00 \\
\hline $\mathrm{Zr}$ & 101.00 & 40.98 & 32.57 \\
\hline Y & 17.85 & 20.23 & 25.88 \\
\hline $\mathrm{Pb}$ & 9.38 & 44.01 & 17.60 \\
\hline Mo & 1.36 & 1.48 & 5.96 \\
\hline $\mathrm{Cu}$ & 21.23 & 4.62 & 206.00 \\
\hline La & 12.14 & 31.63 & 10.66 \\
\hline $\mathrm{Ce}$ & 26.85 & 71.85 & 27.28 \\
\hline $\operatorname{Pr}$ & 3.62 & 8.12 & 3.41 \\
\hline $\mathrm{Nd}$ & 15.40 & 29.84 & 15.21 \\
\hline $\mathrm{Sm}$ & 3.73 & 7.09 & 4.02 \\
\hline Eu & 0.94 & 0.88 & 1.03 \\
\hline Gd & 3.87 & 6.95 & 4.27 \\
\hline $\mathrm{Tb}$ & 0.59 & 1.09 & 0.74 \\
\hline Dy & 3.55 & 5.77 & 4.77 \\
\hline Ho & 0.67 & 0.85 & 0.97 \\
\hline $\mathrm{Er}$ & 1.91 & 2.14 & 2.85 \\
\hline $\mathrm{Tm}$ & 0.26 & 0.27 & 0.42 \\
\hline $\mathrm{Yb}$ & 1.65 & 1.59 & 2.74 \\
\hline
\end{tabular}

The Rare Earth Elements (REE) normalized to chondrite $\mathrm{C} 1$ (Figure 5c) show that, when compared to gabbro-pyroxenite (Sitio Nuevo-1 well) and andesite (Remolino-1 well), the MaHi's syenogranite (Cicuco-22 well: $2.81 / 3.55)$ has a higher enrichment in light REE (LREE, [La/Sm] N) than heavy REE (HREE, $[\mathrm{Gd} / \mathrm{Yb}] \mathrm{N})$. On the other hand, the fractionation value corresponding to HREE in the MaHi's gabbropyroxenite (Sitio Nuevo-1 well: [Gd/Yb] N: 1.26) seems to be related to magmas formed from the partial melting of a plagioclase-spinel mantle. Although there are significant differences in the degree of fractionation of REE in the analyzed samples; this same mantle might be the magmatic source of the syenogranite from the MaHi (Cicuco-22 well: [Gd/Yb] N: 3.55) and andesite from the PlsB (Remolino-1 well: [Gd/Yb] N: 1.9).
The Eu anomaly values (EuN $/ \sqrt{ } \mathrm{SmN} * \mathrm{GdN}$; Figure 5 c) from the samples of wells Remolino-1 (0.76), Cicuco-22 (0.38), and Sitio Nuevo-1 (0.76), point towards a fractionation of plagioclase, indicating a relatively anhydrous indigenous magma which favored the nucleation of plagioclase over the amphibole. Additionally, negative anomalies in $\mathrm{Nb}$, Ta and $\mathrm{Y}$ (Figure 5d), show that the castings related to the three (3) samples are projected towards the typical range of subduction. Geochemical affinity and $\mathrm{Zr}$ vs. $\mathrm{Zr} / \mathrm{Y}$ ratios suggest that the gabbros (pyroxenites) from the MaHi (Sitio Nuevo-1 well), are characteristic of suprasubduction settings (Figure 5e).

The $\mathrm{Ba} / \mathrm{La}$ ratio of samples (Remolino-1: 110.21; Cicuco-22: 80.90 and Sitio Nuevo-1: 47.84 wells) 
allow to suggest that these lithologies were formed in arc environments (threshold values $>20$ ). In addition, according to the tectonic discrimination diagram by Pearce, Harris, \& Tindle, (1984), based upon the $\mathrm{Nb}$ vs. Y ratio, andesite (Remolino-1 well) and syenogranite (Cicuco-22 well) are projected towards the field of granitoids, formed in Volcanic Arc environments (Figure $5 \mathrm{f}$ ). On the other hand, $\mathrm{La} / \mathrm{Yb}$ vs. Sc/Ni ratios (Bailey, 1981) show the andesite (Remolino-1 well: 7.36 vs. 1.10) as characteristic of a thinned continental crust, while the syenogranite (Cicuco-22 well: 19.95 vs. 1.78) is closer to the thick continental crust field (Andes-like).

\section{REFERENCES}

Chappell, B. W., \& White, A. J. R. (1974). Two contrasting granite types. Pacific Geology, 8, 173-174.

Cox, K., Bell, J., \& Pankhurst, R. (1979). The interpretation of igneous rocks. London: George, Allen and Unwin, 450p.

Davies, J.F., \& Whitehead, R.E. (2006). Alkali-alumina and $\mathrm{MgO}$-alumina molar ratios of altered and unaltered rhyolites. Exploration and Mining Geology, 15, 75-88.

Hastie, A. R., Kerr, A. C., Pearce, J. A., \& Mitchell, S. F. (2007). Classification of altered volcanic Island arc rocks using immobile trace eements: development of the Th-Co discrimination diagram. J. Petrol., 48, 2341- 2357. DOI: https://doi.org/10.1093/petrology/egm.

Irvine, T. N., \& Baragar, W. R. A. (1971). A guide to the chemical classification of the common volcanic rocks. Canad. J. Earth Sci., 8 (5), 523-548. DOI: 10.1139/e71-055.

Maniar, P.D., \& Piccoli, P.M. (1989). Tectonic discriminations of granitoids. GSA Bulletin, 101, 635-643.

Pearce, J. A., Harris, N. B. W., \& Tindle, A. J. (1984) Trace element discrimination diagrams for the tectonic interpretation of granitic rocks. J. Petrol., 25 (4), 956-983. DOI: https://doi.org/10.1093/petrology/25.4.956.

Sun, S. -S., \& McDonough. Chemical and isotopic systematics of oceanic basalts: implications for mantle composition and processes. Geol. Soc. London. Sp. Public. DOI: 10.1144/ GSL.SP.1989.042.01.19.

Winchester, J. A., \& Floyd, P. A. (1977). Geochemical discrimination of different magma series and their differentiation products using immobile elements. Chemi. Geol., 20, 325-343. DOI: https://doi.org/10.1016/00092541(77)90057-2.

\section{ANNEX 2.}

Geochemistry from outcrop samples, collected from different localities in the anticlinorium of San Jerónimi (ASJe)

In SJeA, the $\mathrm{SiO}_{2}$ content in the basalt $(30313$ station) and serpentinite (30314 station) samples from the Planeta Rica sector reaches values of $71.60 \%$ and $63.99 \%$ (Table A.2), respectively. Such facts would project these rocks toward the field of acidic rocks, with an inconsistency between lithology and chemical composition. According to the diagrams proposed by Winchester and Floyd (1977) for the classification of the analyzed igneous materials, there is once again, evidence of great differences in terminology when using the $\mathrm{SiO}_{2}$ vs. $\mathrm{Zr} / \mathrm{TiO}_{2}{ }^{*} 0.0001$ and $\mathrm{Zr} / \mathrm{TiO}_{2}$ vs. $\mathrm{Nb} / \mathrm{Y}$ relationships classification diagrams for volcanic rocks (also used to classify intrusive similar samples; Figure A2.1). According to $\mathrm{SiO}_{2}$ vs. $\mathrm{Zr} / \mathrm{TiO}_{2}{ }^{*} 0.0001$ diagram the basalt (station 30313) and tonalite (station 30325) points towards the field of rhyodacitic-dacitic rocks. This fact may be related to the aforementioned high values of $\mathrm{SiO}_{2}$ and therefore, the following chemical interpretations must be considered with caution. However, excluding $\mathrm{SiO}_{2}$ from the classification diagram, in other words, using the $\mathrm{Zr} / \mathrm{TiO}_{2}$ vs. $\mathrm{Nb} / \mathrm{Y}$ diagram, it is evident that the lithologies analyzed are projected towards the fields of andesites/basalts and to the limit of alkaline and subalkaline basalts.
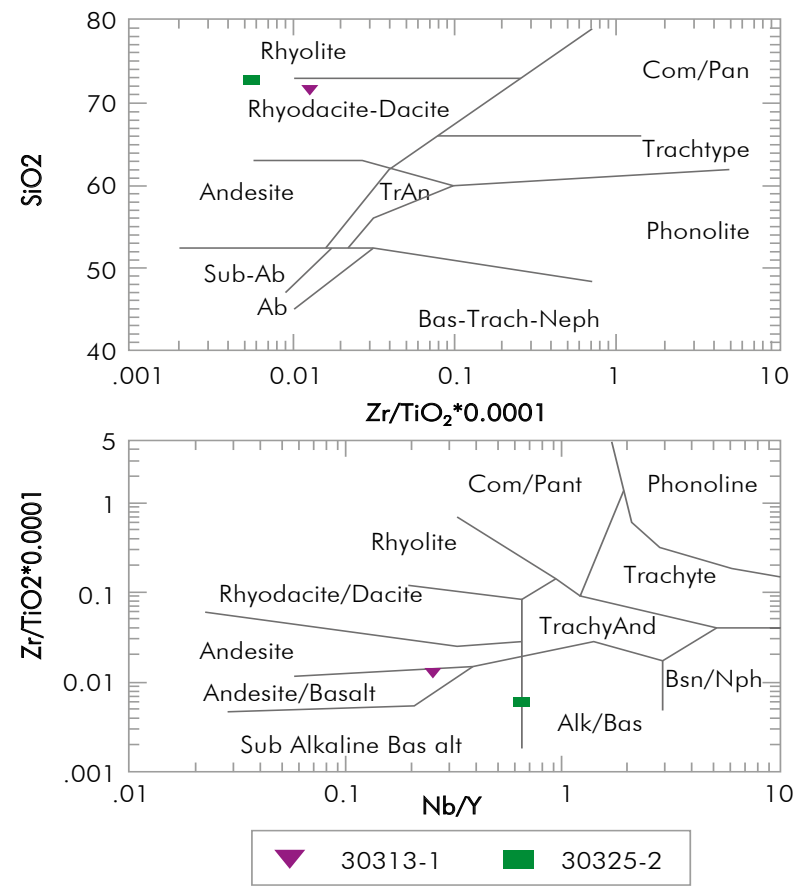

Figure A2.1. Volcanic rocks classification diagram, according to $\mathrm{SiO}_{2}$ vs. $\mathrm{Zr} / \mathrm{TiO}_{2}{ }^{*} 0.0001$ and $\mathrm{Zr} / \mathrm{TiO}_{2}$ vs. $\mathrm{Nb} / \mathrm{Y}$ ratios (Winchester and Floyd, 1977), which shows the projection of the analyzed samples. 
Table A2. Total rock geochemistry data from core samples, collected from different wells drilled in the Lower Magdalena Valley (LMV).

\begin{tabular}{|c|c|c|c|}
\hline Station & 30313-1 & $30314-2$ & $30325-2$ \\
\hline Rock type & Basalt & Serpentinites & Tonalite \\
\hline Location & $\begin{array}{c}\text { Loma Nuevo Paraíso } \\
\text { (Planeta Rica) }\end{array}$ & $\begin{array}{l}\text { Santa Inés Quarry } \\
\text { (Planeta Rica) }\end{array}$ & $\begin{array}{l}\text { El Doce } \\
\text { (Tarazá) }\end{array}$ \\
\hline \multicolumn{4}{|c|}{ Major elements (\%) } \\
\hline $\mathrm{SiO}_{2}$ & 71.60 & 63.99 & 72.73 \\
\hline $\mathrm{Al}_{2} \mathrm{O}_{3}$ & 15.37 & 1.14 & 18.55 \\
\hline $\mathrm{Fe}_{2} \mathrm{O}_{3}$ & 9.69 & 9.89 & 1.75 \\
\hline $\mathrm{MgO}$ & 1.52 & 42.78 & 0.54 \\
\hline $\mathrm{CaO}$ & 2.66 & 0.0 & 1.71 \\
\hline $\mathrm{Na}_{2} \mathrm{O}$ & 7.68 & 0.09 & 4.53 \\
\hline $\mathrm{K}_{2} \mathrm{O}$ & 0.78 & 0.0 & 5.27 \\
\hline $\mathrm{TiO}_{2}$ & 1.24 & 0.02 & 0.30 \\
\hline $\mathrm{P}_{2} \mathrm{O}_{5}$ & 0.23 & 0.04 & 0.11 \\
\hline $\mathrm{MnO}$ & 0.13 & 0.12 & 0.03 \\
\hline $\mathrm{Cr}(\mathrm{ppm})$ & 76.08 & 12.29 & 22.47 \\
\hline $\mathrm{Ni}(\mathrm{ppm})$ & 58.91 & 23.10 & 15.27 \\
\hline Sc (ppm) & 33.26 & 16.85 & 4.18 \\
\hline LOI (\%): $1000^{\circ} \mathrm{C}$ & 3.48 & 16.1 & 1.29 \\
\hline Total sum of oxides & 110.9 & 118.10 & 105.55 \\
\hline \multicolumn{4}{|c|}{ Minor and trace elements (ppm) } \\
\hline $\mathrm{Ba}$ & 447 & 73.79 & 1922 \\
\hline Co & 32.77 & 124 & 4.462 \\
\hline Cs & 0.474 & 0.054 & 1.185 \\
\hline $\mathrm{Ga}$ & 21.98 & 1.951 & 20.4 \\
\hline $\mathrm{Hf}$ & 3.268 & 0.467 & 0.257 \\
\hline $\mathrm{Nb}$ & 6.808 & $<0.865$ & 6.622 \\
\hline $\mathrm{Rb}$ & 19.13 & 2.092 & 74.64 \\
\hline $\mathrm{Sr}$ & 168 & 68.68 & 623 \\
\hline $\mathrm{Ta}$ & 1.287 & 0.891 & 1.061 \\
\hline Th & 1.481 & 0.264 & 16.19 \\
\hline U & 0.407 & $<0.125$ & 0.808 \\
\hline V & 329 & $<0.165$ & 21.31 \\
\hline $\mathrm{Zr}$ & 156 & 28.24 & 17.02 \\
\hline$Y$ & 27.25 & 1.377 & 10.19 \\
\hline Ru & $<0.005$ & $<0.005$ & $<0.005$ \\
\hline $\mathrm{Rh}$ & $<0.25$ & $<0.25$ & $<0.25$ \\
\hline Ir & $<0.165$ & $<0.165$ & $<0.165$ \\
\hline $\operatorname{Re}$ & $<0.145$ & $<0.145$ & $<0.145$ \\
\hline $\mathrm{Pb}$ & 8.631 & 31.16 & 39.58 \\
\hline Mo & 5.093 & 0.858 & 1.458 \\
\hline $\mathrm{Cu}$ & 134 & 10.81 & 6.588 \\
\hline W & $<1.255$ & $<1.255$ & $<.1255$ \\
\hline $\mathrm{La}$ & 12.35 & 1.809 & 68.5 \\
\hline $\mathrm{Ce}$ & 26.05 & 1.812 & 123 \\
\hline
\end{tabular}




\section{CRETACEOUS MAGMATIC ARC AT THE SOUTH OF THE COLOMBIAN CARIBBEAN}

Table A2. Total rock geochemistry data from core samples, collected from different wells drilled in the Lower Magdalena Valley (LMV).(Cont)

\begin{tabular}{|c|c|c|c|}
\hline Station & 30313-1 & $30314-2$ & $30325-2$ \\
\hline Rock type & Basalt & Serpentinites & Tonalite \\
\hline Location & $\begin{array}{l}\text { Loma Nuevo Paraíso } \\
\text { (Planeta Rica) }\end{array}$ & $\begin{array}{l}\text { Santa Inés Quarry } \\
\text { (Planeta Rica) }\end{array}$ & $\begin{array}{l}\text { El Doce } \\
\text { (Tarazá) }\end{array}$ \\
\hline \multicolumn{4}{|c|}{ Minor and trace elements (ppm) } \\
\hline $\operatorname{Pr}$ & 3.895 & $<0.22$ & 14.34 \\
\hline $\mathrm{Nd}$ & 17.21 & 0.846 & 51.67 \\
\hline $\mathrm{Sm}$ & 4.322 & 0.152 & 8.171 \\
\hline Eu & 1.434 & $<0.115$ & 1.791 \\
\hline Gd & 4.974 & 0.198 & 7.225 \\
\hline $\mathrm{Tb}$ & 0.869 & $<0.185$ & 0.802 \\
\hline Dy & 5.13 & 0.24 & 3.362 \\
\hline Ho & 1.071 & $<0.17$ & 0.446 \\
\hline $\mathrm{Er}$ & 2.984 & 0.167 & 0.963 \\
\hline $\mathrm{Tm}$ & 0.425 & $<0.095$ & 0.108 \\
\hline $\mathrm{Yb}$ & 2.271 & $<0.215$ & 0.632 \\
\hline
\end{tabular}

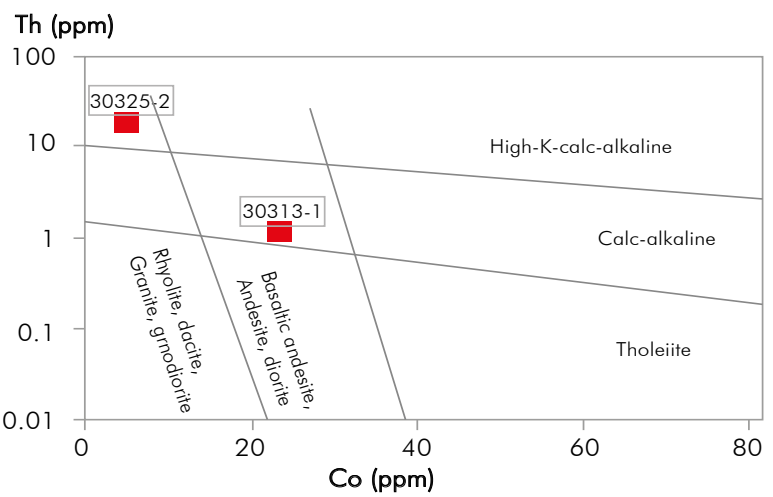

Figure A2.2. Co vs. Th Diagram (Hastie et al., 2007), which shows that the sample from the Planeta Rica sector (30313-1) is projected towards the Calc-Alkaline field, while the Tarazá sector rocks (30325-2) are projected towards the high-potassium calc-alkaline rocks.

According to the classification of the Hastie et al. diagram, (2007), which uses stable elements such as Th and Co (Figure A2.2), we observe that Tonalite (station 30325), is more differentiated (calc-alkaline high in potassium); while Basalt (station 30313) is less differentiated (close to the limit separating the calc-alkaline fields with medium potassium and tholeitics). The difference observed in the Th vs. Co diagram seems to be confirmed in the diagrams represented in Figure A2.3, which show a higher enrichment of Light Rare Earths in the Tonalite sample (station 30325), with respect to the Planeta Rica Basalt (station 30313). On the other hand, the trace elements of these samples (normalized according to the Primitive Mantle), show that these lithologies are characteristic of subduction settings. Likewise, based on these analyses it is also possible to suggest that the rocks from the Planeta Rica basalt (station 30313) are comparatively more primitive (formed in a relatively less evolved-primitive arc) than the Tonalite (station 30325).
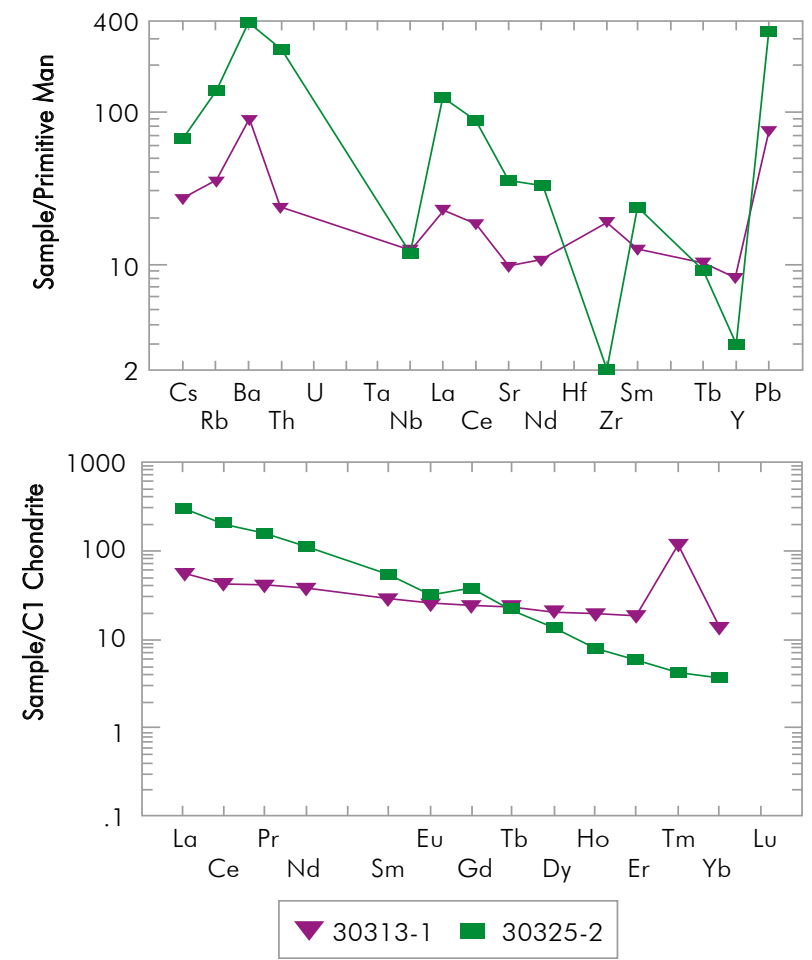

Figure A2.3. Trace elements normalized according to the Primitive Mantle; and Rare Earth patterns obtained from the samples analyzed in this study, normalized according to Chondrite $\mathrm{Cl}$ (data taken from Sun and McDonough, 1989). 
The $\mathrm{SiO}_{2}$ vs. $\mathrm{K}_{2} \mathrm{O}+\mathrm{Na}_{2} \mathrm{O}$ diagram (Figure $\mathrm{A} 2.4$; Irvine and Baragar, 1971) shows that the samples from stations 30313 and 30325 are projected towards the field of sub-alkaline rocks, which opens the possibility that these samples are directly related to subduction settings. According to the Shand Index (Maniar and Piccoli, 1989), the Basalt sample from the Planeta Rica sector (station 30313) is projected towards the field of metaluminic rocks, linked to type-I magmas (Chappell and White, 1992); while the Tonalite from the Tarazá sector (station 30325) is projected towards the field of peraluminic rocks, linked to type-S magmas. The latter may suggest either a fractionation process of initially metaluminic magmas, or simply cortical contamination processes.

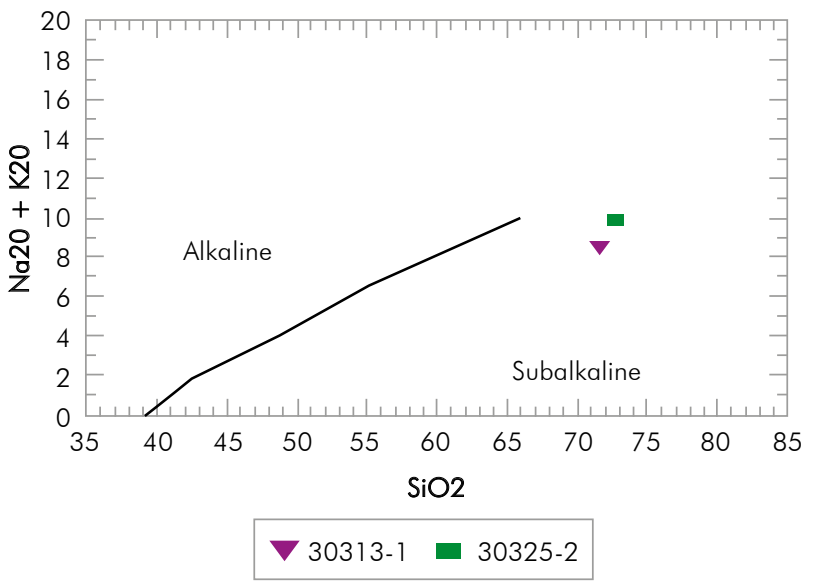

Figure A2.4. $\mathrm{SiO}_{2}$ vs. $\mathrm{K}_{2} \mathrm{O}+\mathrm{Na}_{2} \mathrm{O}$ Geochemical Diagram (Irvine and Baragar, 1971), which show the magma series, projecting the two samples analyzed from the CPSJ basement.

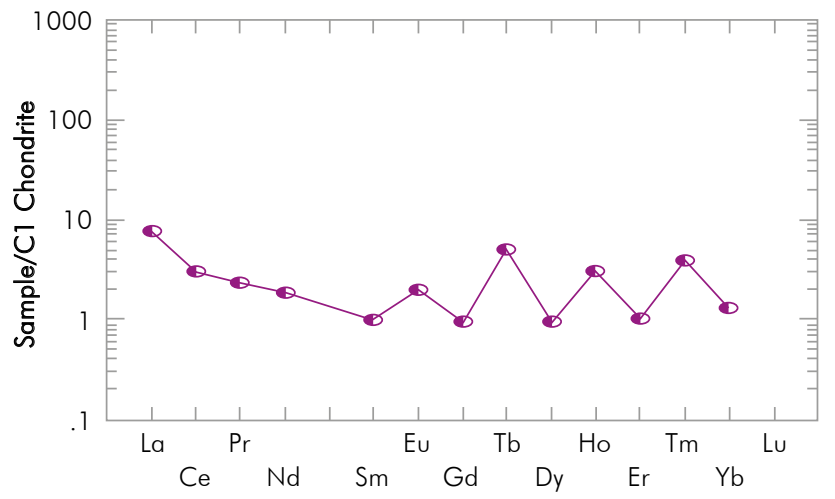

Figure A2.5. Rare Earth Patterns obtained from the analyzed serpentinic sample (30314-2). Normalization according to Chondrite $\mathrm{Cl}$ (data taken from Sun and McDonough, 1989).

Considering that it has the highest content of $\mathrm{MgO}$ $(42.78 \%)$ and the lowest content of $\mathrm{Al}_{2} \mathrm{O}_{3}(1.14 \%)$ the Serpentinite (station 30314) represents the more primitive rock. The high $\mathrm{MgO}$ content is characteristic of peridotitic materials (ultramafic, primitive rocks) as of komatiitic, picritic and boninite materials. The REE pattern for serpentinite also shows a primitive characteristic, although it has a light enrichment in LREE (Figure A2.5). This may be interpreted as related to mantle wedge hydration processes from allochtonous fluids released from dehydration processes of the materials that were then subducted. In this sense, it is proposed that the serpentization of these ultrabasic rocks was the result of a hypogene hydrothermal alteration process (processes implying metasomatism).

\section{REFERENCES}

Chappell, B. W., \& White, A. J. R. (1974). Two contrasting granite types. Pacific Geology, 8, 173-174.

Cox, K., Bell, J., \& Pankhurst, R. (1979). The interpretation of igneous rocks. London: George, Allen and Unwin, 450p.

Davies, J.F., \& Whitehead, R.E. (2006). Alkali-alumina and $\mathrm{MgO}$-alumina molar ratios of altered and unaltered rhyolites. Explor. Mining Geol., 15, 75-88. DOI: 10.2113/ gsemg.15.1-2.75.

Hastie, A. R., Kerr, A. C., Pearce, J. A., \& Mitchell, S. F. (2007). Classification of altered volcanic island arc rocks using immobile trace elements: development of the Th-Co discrimination diagram. J. Petrol., 48, 2341- 2357. DOI: https://doi.org/10.1093/petrology/egm062.

Irvine, T. N., \& Baragar, W. R. A. (1971). A guide to the chemical classification of the common volcanic rocks. Canad. J. Earth Sci., 8, 523-548. DOI: 10.1139/e71-055.

Maniar, P.D., \& Piccoli, P.M. (1989). Tectonic discriminations of granitoids. GSA Bulletin, 101, 635-643.

Pearce, J.A., Harris, N. B. W., \& Tindle, A.J. (1984) Trace element discrimination diagrams for the tectonic interpretation of granitic rocks. J. Petrol., 25 (4), 956-83. DOI: https://doi.org/10.1093/petrology/25.4.95.

Sun, S. -S., \& McDonough. Chemical and isotopic systematics of oceanic basalts: implications for mantle composition and processes. Geol. Soc. London. Sp. Public. DOI: 10.1144/ GSL.SP.1989.042.01.19.

Winchester, J. A., \& Floyd, P. A. (1977). Geochemical discrimination of different magma series and their differentiation products using immobile elements. Chem. Geol., 20, 325-343. DOI: https://doi.org/10.1016/00092541(77)90057-2. 
BASEMENT CHARACTERISTICS IN THE LOWER MAGDALENA VALLEY AND THE SINÚ AND SAN JACINTO FOLD BELTS: EVIDENCE OF A LATE CRETACEOUS MAGMATIC ARC AT THE SOUTH OF THE COLOMBIAN CARIBBEAN

\section{ANNEX 3. Geochronology}

Table A3. Geochronology data samples of the Cicuco-22, Coral-9 and Sitio Nuevo-1 wells, Lower Magdalena Valley (LMV).

\begin{tabular}{|c|c|c|c|c|c|c|c|c|c|c|c|c|}
\hline Sample & U & Th & $238 U$ & 1 sigma & $207 \mathrm{~Pb}$ & 1 sigma & $206 / 238$ & 1 sigma & $207 / 206$ & 1 sigma & Best age & 1 sigma \\
\hline Name & ppm & U & $206 \mathrm{~Pb}$ & $\%$ error & $206 \mathrm{~Pb}$ & $\%$ error & age & abs err & age & abs err & & $\begin{array}{c}\text { abs err } \\
\text { Ma }\end{array}$ \\
\hline CICUCO-22_37 & 1078.04 & 0.13 & 8.01 & 0.02 & 0.07 & 0.01 & 758.75 & 10.95 & 887.64 & 14.71 & 758.75 & 10.95 \\
\hline CICUCO-22_36 & 1409.78 & 0.09 & 7.16 & 0.02 & 0.07 & 0.01 & 843.18 & 14.23 & 960.40 & 14.85 & 843.18 & 14.23 \\
\hline CICUCO-22_35 & 373.88 & 0.69 & 75.66 & 0.02 & 0.05 & 0.02 & 84.64 & 1.45 & 306.97 & 37.06 & 84.64 & 1.45 \\
\hline CICUCO-22_34 & 588.03 & 0.70 & 75.72 & 0.02 & 0.05 & 0.01 & 84.58 & 1.45 & 245.52 & 33.00 & 84.58 & 1.45 \\
\hline CICUCO-22_33 & 235.20 & 0.41 & 71.35 & 0.03 & 0.06 & 0.02 & 89.72 & 2.29 & 672.17 & 49.65 & 89.72 & 2.29 \\
\hline CICUCO-22_32 & 708.64 & 0.03 & 2.15 & 0.01 & 0.17 & 0.01 & 2459.41 & 28.69 & 2534.19 & 10.51 & 2534.19 & 10.51 \\
\hline CICUCO-22_31 & 782.28 & 0.04 & 2.41 & 0.01 & 0.17 & 0.01 & 2238.68 & 27.58 & 2527.14 & 10.33 & 2527.14 & 10.33 \\
\hline CICUCO-22_30 & 260.82 & 1.03 & 14.14 & 0.02 & 0.06 & 0.01 & 440.47 & 6.51 & 445.31 & 20.00 & 440.47 & 6.51 \\
\hline CICUCO-22_29 & 775.23 & 0.56 & 76.19 & 0.02 & 0.05 & 0.02 & 84.06 & 1.50 & 182.54 & 36.05 & 84.06 & 1.50 \\
\hline CICUCO-22_28 & 379.19 & 0.64 & 70.44 & 0.02 & 0.05 & 0.02 & 90.88 & 2.11 & 223.84 & 52.02 & 90.88 & 2.11 \\
\hline CICUCO-22_27 & 1623.03 & 1.03 & 75.36 & 0.01 & 0.05 & 0.01 & 84.98 & 1.24 & 85.09 & 24.13 & 84.98 & 1.24 \\
\hline CICUCO-22_26 & 558.65 & 0.72 & 76.64 & 0.02 & 0.05 & 0.01 & 83.57 & 1.34 & 208.67 & 32.35 & 83.57 & 1.34 \\
\hline CICUCO-22_25 & 1016.69 & 1.17 & 77.30 & 0.02 & 0.05 & 0.01 & 82.86 & 1.31 & 114.08 & 30.45 & 82.86 & 1.31 \\
\hline CICUCO-22_24 & 394.11 & 0.55 & 76.58 & 0.02 & 0.05 & 0.02 & 83.63 & 1.49 & 219.55 & 35.34 & 83.63 & 1.49 \\
\hline CICUCO-22_23 & 370.55 & 0.55 & 76.35 & 0.02 & 0.05 & 0.02 & 83.88 & 1.43 & 92.84 & 39.28 & 83.88 & 1.43 \\
\hline CICUCO-22_22 & 499.93 & 0.76 & 76.62 & 0.02 & 0.05 & 0.02 & 83.59 & 1.34 & 218.75 & 37.90 & 83.59 & 1.34 \\
\hline CICUCO-22_21 & 434.22 & 0.76 & 75.58 & 0.02 & 0.05 & 0.02 & 84.73 & 1.37 & 121.54 & 40.86 & 84.73 & 1.37 \\
\hline CICUCO-22_20 & 480.25 & 0.68 & 75.38 & 0.02 & 0.05 & 0.02 & 84.96 & 1.42 & 111.63 & 35.17 & 84.96 & 1.42 \\
\hline CICUCO-22_19 & 2354.47 & 1.32 & 75.75 & 0.01 & 0.05 & 0.01 & 84.54 & 1.22 & 110.05 & 19.64 & 84.54 & 1.22 \\
\hline CICUCO-22_18 & 708.71 & 0.78 & 76.70 & 0.01 & 0.05 & 0.01 & 83.50 & 0.95 & 79.11 & 31.03 & 83.50 & 0.95 \\
\hline CICUCO-22_17 & 249.57 & 0.82 & 72.84 & 0.01 & 0.05 & 0.02 & 87.90 & 1.18 & 121.13 & 53.79 & 87.90 & 1.18 \\
\hline CICUCO-22_16 & 484.59 & 0.39 & 5.11 & 0.01 & 0.08 & 0.01 & 1151.93 & 9.23 & 1199.60 & 13.38 & 1199.60 & 13.38 \\
\hline CICUCO-22_15 & 888.31 & 0.16 & 6.67 & 0.01 & 0.07 & 0.01 & 901.04 & 7.36 & 961.23 & 13.98 & 901.04 & 7.36 \\
\hline CICUCO-22_14 & 55.57 & 0.82 & 2.14 & 0.01 & 0.18 & 0.01 & 2468.87 & 20.78 & 2659.89 & 11.80 & 2659.89 & 11.80 \\
\hline CICUCO-22_13 & 148.01 & 0.39 & 2.15 & 0.03 & 0.16 & 0.01 & 2462.31 & 69.08 & 2502.20 & 14.39 & 2502.20 & 14.39 \\
\hline CICUCO-22_12 & 601.50 & 0.55 & 76.02 & 0.01 & 0.05 & 0.01 & 84.25 & 0.95 & 124.25 & 28.35 & 84.25 & 0.95 \\
\hline CICUCO-22_11 & 549.86 & 0.60 & 75.61 & 0.01 & 0.05 & 0.01 & 84.70 & 0.96 & 121.24 & 33.77 & 84.70 & 0.96 \\
\hline CICUCO-22_10 & 532.70 & 0.58 & 75.70 & 0.01 & 0.05 & 0.02 & 84.60 & 0.93 & 223.60 & 39.20 & 84.60 & 0.93 \\
\hline CICUCO-22_9 & 458.60 & 0.57 & 77.14 & 0.01 & 0.05 & 0.02 & 83.03 & 1.01 & 85.25 & 36.18 & 83.03 & 1.01 \\
\hline CICUCO-22_8 & 461.70 & 0.55 & 3.65 & 0.01 & 0.11 & 0.01 & 1562.83 & 14.09 & 1723.43 & 12.12 & 1723.43 & 12.12 \\
\hline CICUCO-22_7 & 1039.30 & 0.35 & 3.76 & 0.01 & 0.11 & 0.01 & 1521.55 & 11.17 & 1728.54 & 11.59 & 1728.54 & 11.59 \\
\hline CICUCO-22_6 & 439.46 & 0.55 & 75.22 & 0.01 & 0.05 & 0.01 & 85.13 & 1.07 & 190.29 & 33.99 & 85.13 & 1.07 \\
\hline CICUCO-22_5 & 402.61 & 0.58 & 74.74 & 0.01 & 0.05 & 0.02 & 85.68 & 1.14 & 121.77 & 36.31 & 85.68 & 1.14 \\
\hline CICUCO-22_4 & 511.35 & 0.65 & 75.34 & 0.01 & 0.05 & 0.02 & 85.00 & 1.23 & 122.51 & 39.13 & 85.00 & 1.23 \\
\hline CICUCO-22_3 & 600.98 & 0.65 & 75.77 & 0.01 & 0.05 & 0.01 & 84.52 & 1.00 & 151.77 & 29.49 & 84.52 & 1.00 \\
\hline CICUCO-22_2 & 252.05 & 0.43 & 75.76 & 0.01 & 0.05 & 0.02 & 84.53 & 1.25 & 85.65 & 47.16 & 84.53 & 1.25 \\
\hline CICUCO-22_1 & 296.94 & 0.35 & 5.66 & 0.01 & 0.07 & 0.01 & 1048.90 & 8.54 & 1042.44 & 14.34 & 1042.44 & 14.34 \\
\hline
\end{tabular}


Table A3. (Continuation) Geochronology data samples of the Cicuco-22, Coral-9 and Sitio Nuevo-1 wells, Lower Magdalena Valley (LMV).

\begin{tabular}{|c|c|c|c|c|c|c|c|c|c|c|c|c|}
\hline Sample & $U$ & Th & $238 U$ & 1 sigma & $207 \mathrm{~Pb}$ & 1 sigma & $206 / 238$ & 1 sigma & $207 / 206$ & 1 sigma & Best age & 1 sigma \\
\hline Name & ppm & $U$ & $206 \mathrm{~Pb}$ & $\%$ error & $206 \mathrm{~Pb}$ & $\%$ error & age & abs err & age & abs err & & $\begin{array}{c}\text { abs err } \\
\text { Ma }\end{array}$ \\
\hline CORAL-9_38 & 191.75 & 0.43 & 83.74 & 0.02 & 0.06 & 0.03 & 76.53 & 1.63 & 528.31 & 61.08 & 76.53 & 1.63 \\
\hline CORAL-9_37 & 623.22 & 0.16 & 27.62 & 0.02 & 0.05 & 0.02 & 229.30 & 4.15 & 306.79 & 36.81 & 229.30 & 4.15 \\
\hline CORAL-9_36 & 612.62 & 0.51 & 20.84 & 0.01 & 0.05 & 0.01 & 302.09 & 3.37 & 330.12 & 16.91 & 302.09 & 3.37 \\
\hline CORAL-9_35 & 73.98 & 0.19 & 27.15 & 0.02 & 0.05 & 0.02 & 233.17 & 3.72 & 378.40 & 48.03 & 233.17 & 3.72 \\
\hline CORAL-9_34 & 380.34 & 0.95 & 21.47 & 0.02 & 0.06 & 0.01 & 293.47 & 5.71 & 505.40 & 16.46 & 293.47 & 5.71 \\
\hline CORAL-9_33 & 59.61 & 0.27 & 27.02 & 0.02 & 0.06 & 0.03 & 234.28 & 3.85 & 473.40 & 61.05 & 234.28 & 3.85 \\
\hline CORAL-9_32 & 868.14 & 0.10 & 26.19 & 0.02 & 0.05 & 0.01 & 241.53 & 3.96 & 248.42 & 22.85 & 241.53 & 3.96 \\
\hline CORAL-9_31 & 684.81 & 0.15 & 26.54 & 0.01 & 0.05 & 0.01 & 238.46 & 3.39 & 379.58 & 15.60 & 238.46 & 3.39 \\
\hline CORAL-9_30 & 826.55 & 0.18 & 26.16 & 0.01 & 0.05 & 0.01 & 241.81 & 2.56 & 259.10 & 15.39 & 241.81 & 2.56 \\
\hline CORAL-9_29 & 200.56 & 0.32 & 81.96 & 0.02 & 0.06 & 0.02 & 78.17 & 1.37 & 540.12 & 49.84 & 78.17 & 1.37 \\
\hline CORAL-9_28 & 477.91 & 1.29 & 5.88 & 0.01 & 0.07 & 0.01 & 1013.26 & 9.68 & 1046.15 & 10.24 & 1046.15 & 10.24 \\
\hline CORAL-9_27 & 695.77 & 0.33 & 26.68 & 0.01 & 0.05 & 0.01 & 237.18 & 2.50 & 262.60 & 16.85 & 237.18 & 2.50 \\
\hline CORAL-9_26 & 182.51 & 0.68 & 6.23 & 0.02 & 0.08 & 0.01 & 959.12 & 14.59 & 1166.72 & 11.98 & 959.12 & 14.59 \\
\hline CORAL-9_25 & 467.94 & 0.76 & 86.82 & 0.01 & 0.05 & 0.02 & 73.82 & 0.92 & 133.86 & 36.50 & 73.82 & 0.92 \\
\hline CORAL-9_24 & 652.06 & 0.08 & 27.04 & 0.02 & 0.05 & 0.02 & 234.14 & 3.52 & 276.49 & 35.88 & 234.14 & 3.52 \\
\hline CORAL-9_23 & 155.40 & 0.42 & 89.41 & 0.02 & 0.05 & 0.03 & 71.70 & 1.29 & 238.58 & 59.72 & 71.70 & 1.29 \\
\hline CORAL-9_22 & 416.36 & 0.98 & 26.27 & 0.01 & 0.05 & 0.01 & 240.83 & 2.76 & 242.72 & 21.17 & 240.83 & 2.76 \\
\hline CORAL-9_21 & 1150.74 & 0.13 & 26.79 & 0.01 & 0.05 & 0.01 & 236.26 & 2.61 & 238.30 & 15.44 & 236.26 & 2.61 \\
\hline CORAL-9_20 & 76.74 & 0.29 & 28.04 & 0.02 & 0.05 & 0.02 & 225.89 & 3.67 & 379.16 & 43.68 & 225.89 & 3.67 \\
\hline CORAL-9_19 & 1187.75 & 0.08 & 27.60 & 0.02 & 0.05 & 0.01 & 229.44 & 3.76 & 266.03 & 30.42 & 229.44 & 3.76 \\
\hline CORAL-9_18 & 160.53 & 0.37 & 88.32 & 0.02 & 0.05 & 0.02 & 72.58 & 1.43 & 274.48 & 53.99 & 72.58 & 1.43 \\
\hline CORAL-9_17 & 635.11 & 0.22 & 14.27 & 0.02 & 0.06 & 0.01 & 436.55 & 8.49 & 585.49 & 13.33 & 436.55 & 8.49 \\
\hline CORAL-9_16 & 911.23 & 0.49 & 20.09 & 0.02 & 0.07 & 0.01 & 313.08 & 7.24 & 950.52 & 12.75 & 313.08 & 7.24 \\
\hline CORAL-9_15 & 561.33 & 0.14 & 31.75 & 0.02 & 0.05 & 0.01 & 199.90 & 3.11 & 287.17 & 22.44 & 199.90 & 3.11 \\
\hline CORAL-9_14 & 263.26 & 0.24 & 5.64 & 0.01 & 0.08 & 0.01 & 1052.51 & 10.83 & 1169.97 & 10.98 & 1169.97 & 10.98 \\
\hline CORAL-9_13 & 281.72 & 0.64 & 84.37 & 0.01 & 0.06 & 0.02 & 75.96 & 1.13 & 447.02 & 36.01 & 75.96 & 1.13 \\
\hline CORAL-9_12 & 264.41 & 0.36 & 9.96 & 0.02 & 0.07 & 0.01 & 616.96 & 10.09 & 1014.76 & 17.12 & 616.96 & 10.09 \\
\hline CORAL-9_11 & 862.39 & 0.08 & 27.19 & 0.01 & 0.05 & 0.01 & 232.83 & 2.40 & 297.36 & 15.93 & 232.83 & 2.40 \\
\hline CORAL-9_10 & 819.38 & 0.24 & 25.82 & 0.01 & 0.05 & 0.01 & 244.98 & 2.77 & 371.09 & 16.97 & 244.98 & 2.77 \\
\hline CORAL-9_9 & 632.51 & 0.08 & 27.09 & 0.01 & 0.05 & 0.01 & 233.71 & 2.40 & 239.55 & 18.02 & 233.71 & 2.40 \\
\hline CORAL-9_8 & 1039.84 & 0.06 & 14.54 & 0.01 & 0.06 & 0.01 & 428.69 & 6.16 & 507.80 & 13.98 & 428.69 & 6.16 \\
\hline CORAL-9_7 & 23.87 & 0.23 & 29.31 & 0.03 & 0.06 & 0.03 & 216.30 & 5.55 & 451.40 & 68.42 & 216.30 & 5.55 \\
\hline CORAL-9_6 & 726.11 & 0.20 & 26.55 & 0.01 & 0.05 & 0.01 & 238.38 & 2.71 & 256.36 & 16.02 & 238.38 & 2.71 \\
\hline CORAL-9_5 & 737.99 & 0.50 & 27.47 & 0.01 & 0.05 & 0.01 & 230.53 & 2.55 & 280.95 & 17.32 & 230.53 & 2.55 \\
\hline CORAL-9_4 & 966.78 & 0.08 & 28.17 & 0.01 & 0.05 & 0.01 & 224.86 & 3.28 & 206.59 & 26.53 & 224.86 & 3.28 \\
\hline CORAL-9_3 & 648.22 & 1.45 & 5.62 & 0.01 & 0.10 & 0.01 & 1054.94 & 12.28 & 1711.98 & 9.62 & 1711.98 & 9.62 \\
\hline CORAL-9_2 & 1805.82 & 0.06 & 27.14 & 0.01 & 0.05 & 0.01 & 233.25 & 2.52 & 290.07 & 12.52 & 233.25 & 2.52 \\
\hline CORAL-9_1 & 192.73 & 0.45 & 86.85 & 0.02 & 0.05 & 0.02 & 73.80 & 1.16 & 170.83 & 53.61 & 73.80 & 1.16 \\
\hline
\end{tabular}


BASEMENT CHARACTERISTICS IN THE LOWER MAGDALENA VALLEY AND THE SINÚ AND SAN JACINTO FOLD BELTS: EVIDENCE OF A LATE CRETACEOUS MAGMATIC ARC AT THE SOUTH OF THE COLOMBIAN CARIBBEAN

Table A3. (Continuation) Geochronology data samples of the Cicuco-22, Coral-9 and Sitio Nuevo-1 wells, Lower Magdalena Valley (LMV).

\begin{tabular}{|c|c|c|c|c|c|c|c|c|c|c|c|c|}
\hline Sample & $U$ & Th & $238 U$ & 1 sigma & $207 \mathrm{~Pb}$ & 1 sigma & $206 / 238$ & 1 sigma & $207 / 206$ & 1 sigma & Best age & 1 sigma \\
\hline Name & ppm & U & $206 \mathrm{~Pb}$ & $\%$ error & $206 \mathrm{~Pb}$ & $\%$ error & age & abs err & age & abs err & & $\begin{array}{c}\text { abs err } \\
\text { Ma }\end{array}$ \\
\hline SITIO NUEVO_5311_35 & 277.27 & 0.78 & 20.91 & 0.02 & 0.05 & 0.01 & 301.09 & 4.62 & 261.89 & 22.05 & 301.09 & 4.62 \\
\hline SITIO NUEVO_5311_34 & 251.30 & 0.87 & 21.27 & 0.02 & 0.05 & 0.01 & 296.20 & 4.76 & 284.15 & 27.01 & 296.20 & 4.76 \\
\hline SITIO NUEVO_5311_33 & 335.76 & 0.87 & 21.15 & 0.02 & 0.05 & 0.01 & 297.79 & 4.55 & 296.27 & 20.58 & 297.79 & 4.55 \\
\hline SITIO NUEVO_5311_32 & 164.43 & 0.79 & 20.79 & 0.02 & 0.05 & 0.01 & 302.79 & 4.72 & 261.85 & 27.75 & 302.79 & 4.72 \\
\hline SITIO NUEVO_5311_31 & 103.59 & 0.68 & 21.10 & 0.02 & 0.05 & 0.02 & 298.53 & 5.11 & 278.20 & 34.06 & 298.53 & 5.11 \\
\hline SITIO NUEVO_5311_30 & 619.73 & 0.71 & 20.93 & 0.01 & 0.05 & 0.01 & 300.81 & 4.33 & 285.91 & 15.84 & 300.81 & 4.33 \\
\hline SITIO NUEVO_5311_29 & 157.44 & 0.80 & 20.70 & 0.02 & 0.05 & 0.01 & 304.15 & 4.54 & 268.19 & 26.92 & 304.15 & 4.54 \\
\hline SITIO NUEVO_5311_28 & 150.35 & 0.88 & 20.98 & 0.02 & 0.05 & 0.01 & 300.15 & 4.79 & 314.56 & 29.98 & 300.15 & 4.79 \\
\hline SITIO NUEVO_5311_27 & 272.89 & 0.82 & 21.00 & 0.02 & 0.05 & 0.01 & 299.94 & 4.82 & 330.82 & 22.54 & 299.94 & 4.82 \\
\hline SITIO NUEVO_5311_26 & 267.63 & 0.75 & 21.25 & 0.02 & 0.05 & 0.01 & 296.42 & 4.48 & 308.19 & 20.47 & 296.42 & 4.48 \\
\hline SITIO NUEVO_5311_25 & 261.65 & 0.79 & 20.83 & 0.02 & 0.05 & 0.01 & 302.34 & 4.57 & 294.89 & 24.03 & 302.34 & 4.57 \\
\hline SITIO NUEVO_5311_24 & 126.10 & 0.72 & 21.28 & 0.02 & 0.05 & 0.01 & 295.97 & 4.81 & 350.42 & 29.47 & 295.97 & 4.81 \\
\hline SITIO NUEVO_5311_23 & 132.83 & 0.88 & 21.16 & 0.02 & 0.05 & 0.01 & 297.72 & 4.85 & 303.08 & 30.64 & 297.72 & 4.85 \\
\hline SITIO NUEVO_5311_22 & 92.47 & 0.78 & 21.10 & 0.01 & 0.05 & 0.02 & 298.55 & 4.31 & 318.46 & 34.10 & 298.55 & 4.31 \\
\hline SITIO NUEVO_5311_21 & 185.43 & 0.87 & 20.99 & 0.01 & 0.05 & 0.01 & 300.00 & 3.72 & 343.85 & 25.27 & 300.00 & 3.72 \\
\hline SITIO NUEVO_5311_20 & 224.71 & 0.97 & 21.20 & 0.01 & 0.05 & 0.01 & 297.14 & 3.52 & 334.60 & 21.82 & 297.14 & 3.52 \\
\hline SITIO NUEVO_5311_19 & 384.37 & 1.10 & 20.96 & 0.01 & 0.05 & 0.01 & 300.38 & 3.30 & 375.02 & 17.78 & 300.38 & 3.30 \\
\hline SITIO NUEVO_5311_18 & 263.48 & 0.82 & 20.81 & 0.01 & 0.05 & 0.01 & 302.61 & 3.52 & 260.91 & 25.14 & 302.61 & 3.52 \\
\hline SITIO NUEVO_5311_17 & 102.35 & 0.55 & 21.16 & 0.01 & 0.05 & 0.02 & 297.69 & 4.33 & 311.10 & 34.84 & 297.69 & 4.33 \\
\hline SITIO NUEVO_5311_16 & 185.58 & 0.91 & 20.81 & 0.01 & 0.05 & 0.01 & 302.57 & 3.58 & 310.29 & 27.12 & 302.57 & 3.58 \\
\hline SITIO NUEVO_5311_15 & 177.68 & 0.87 & 21.13 & 0.01 & 0.05 & 0.01 & 298.13 & 3.49 & 281.57 & 28.75 & 298.13 & 3.49 \\
\hline SITIO NUEVO_5311_14 & 213.62 & 0.84 & 20.79 & 0.01 & 0.05 & 0.01 & 302.79 & 3.54 & 296.06 & 26.63 & 302.79 & 3.54 \\
\hline SITIO NUEVO_5311_13 & 425.61 & 0.64 & 20.73 & 0.01 & 0.05 & 0.01 & 303.77 & 3.42 & 332.02 & 18.10 & 303.77 & 3.42 \\
\hline SITIO NUEVO_5311_12 & 174.38 & 0.79 & 20.59 & 0.01 & 0.05 & 0.01 & 305.67 & 4.03 & 320.53 & 26.40 & 305.67 & 4.03 \\
\hline SITIO NUEVO_5311_11 & 156.46 & 0.44 & 20.74 & 0.01 & 0.05 & 0.01 & 303.59 & 3.92 & 285.76 & 30.66 & 303.59 & 3.92 \\
\hline SITIO NUEVO_5311_10 & 161.50 & 0.53 & 21.28 & 0.01 & 0.05 & 0.01 & 296.05 & 3.78 & 365.94 & 26.87 & 296.05 & 3.78 \\
\hline SITIO NUEVO_5311_9 & 180.17 & 0.71 & 21.13 & 0.01 & 0.05 & 0.01 & 298.09 & 3.72 & 330.59 & 26.26 & 298.09 & 3.72 \\
\hline SITIO NUEVO_5311_8 & 386.47 & 0.75 & 20.99 & 0.01 & 0.05 & 0.01 & 300.05 & 3.52 & 347.95 & 19.59 & 300.05 & 3.52 \\
\hline SITIO NUEVO_5311_7 & 247.80 & 0.42 & 21.13 & 0.01 & 0.05 & 0.01 & 298.10 & 3.43 & 345.40 & 23.67 & 298.10 & 3.43 \\
\hline SITIO NUEVO_5311_6 & 195.20 & 0.87 & 20.88 & 0.01 & 0.05 & 0.01 & 301.54 & 3.71 & 281.33 & 25.66 & 301.54 & 3.71 \\
\hline SITIO NUEVO_5311_5 & 361.75 & 0.79 & 20.79 & 0.01 & 0.05 & 0.01 & 302.84 & 3.33 & 278.83 & 19.57 & 302.84 & 3.33 \\
\hline SITIO NUEVO_5311_4 & 138.54 & 0.65 & 21.11 & 0.01 & 0.05 & 0.01 & 298.41 & 3.65 & 293.29 & 33.43 & 298.41 & 3.65 \\
\hline SITIO NUEVO_5311_3 & 127.49 & 0.45 & 21.09 & 0.01 & 0.05 & 0.01 & 298.65 & 3.84 & 253.30 & 31.48 & 298.65 & 3.84 \\
\hline SITIO NUEVO_5311_2 & 190.97 & 0.91 & 21.23 & 0.01 & 0.05 & 0.01 & 296.65 & 3.37 & 294.84 & 23.02 & 296.65 & 3.37 \\
\hline
\end{tabular}




\section{ANNEX 4. CANSONA FORMATION AND OCEANIC COMPLEX(BASEMENT) OVERVIEW}

\section{San Carlos Quarry}

The Cansona Formation and the typical rocks from an oceanic complex, outcropping in areas of the San Carlos Quarry (Figures 1, 2 and 7 of the main text; Tables 1 and 2 of the main text), are located within the jurisdiction of the Santa Cruz de Lorica Municipality (Córdoba Department). This sector includes rocks from the Cansona Formation (Figure A4.1); mainly represented by alternating cherts, fine-grain sandstone and calcareous mudstone: which are overlapped by a greenish-grey, loose material, with punctual spheroidal disjunctions (derived from supergene alteration processes), which have hydrothermal filling with thicknesses under $1 \mathrm{~cm}$.

As discussed in Annex 2, the protolith of this greenish-gray material is a saprolitized peridotite rock, the presence of which on the Cansona Formation rocks, and the evidence of a strong refolding in this sector (Figure A4.2), are elements allowing to establish the existence of deformation features related to thrusting phenomena in the San Carlos Quarry. Given that saprolitized peridotites have quartz-albite parallel veins (sheet veins), arranged in parallel to the fault plain separating the two aforementioned lithologies, it is possible to suggest that this deformation event was joined by fluid-escape phenomena.

\section{Loma Grande Quarry}

The Cansona Formation and the typical rocks from an oceanic complex, outcropping in specific areas of the Loma Grande Quarry (Figures 1, 2 and 7 of the main text; Tables 1 and 2 of the main text), are located within the jurisdiction of the Montería Municipality (Córdoba Department). In this sector we observe once again a succession of the Cansona Formation rocks (Figure A4.2); mainly represented by alternating chert, finegrain sandstone and calcareous mudstone; overlapped by an earthy-like, completely crumbly (non-cohesive) material, which is considered to be derived from supergene alteration processes of peridotitic materials, as mentioned above. These earthy-like rocks overlie the sedimentary rocks of the Cansona Formation, which develop light green (apple green) tones at a local level, characteristic of epigenetic processes. This green color of the Cansona Formation rocks, especially when these are located under the earthy layers, is considered related to downward migration processes of meteoric fluids, in which $\mathrm{Ni}$ (among other possible elements is re-mobilized). This element is usually released when peridotitic rocks experience laterization as a result of supergene alteration processes.

As in the case of the San Carlos Quarry, the presence of this peridotitic material on the Cansona Formation rocks and the evidence of strong refolding in this sector are elements which allow establishing the existence of deformation features associated to thrusting phenomena in the Loma Grande Quarry.

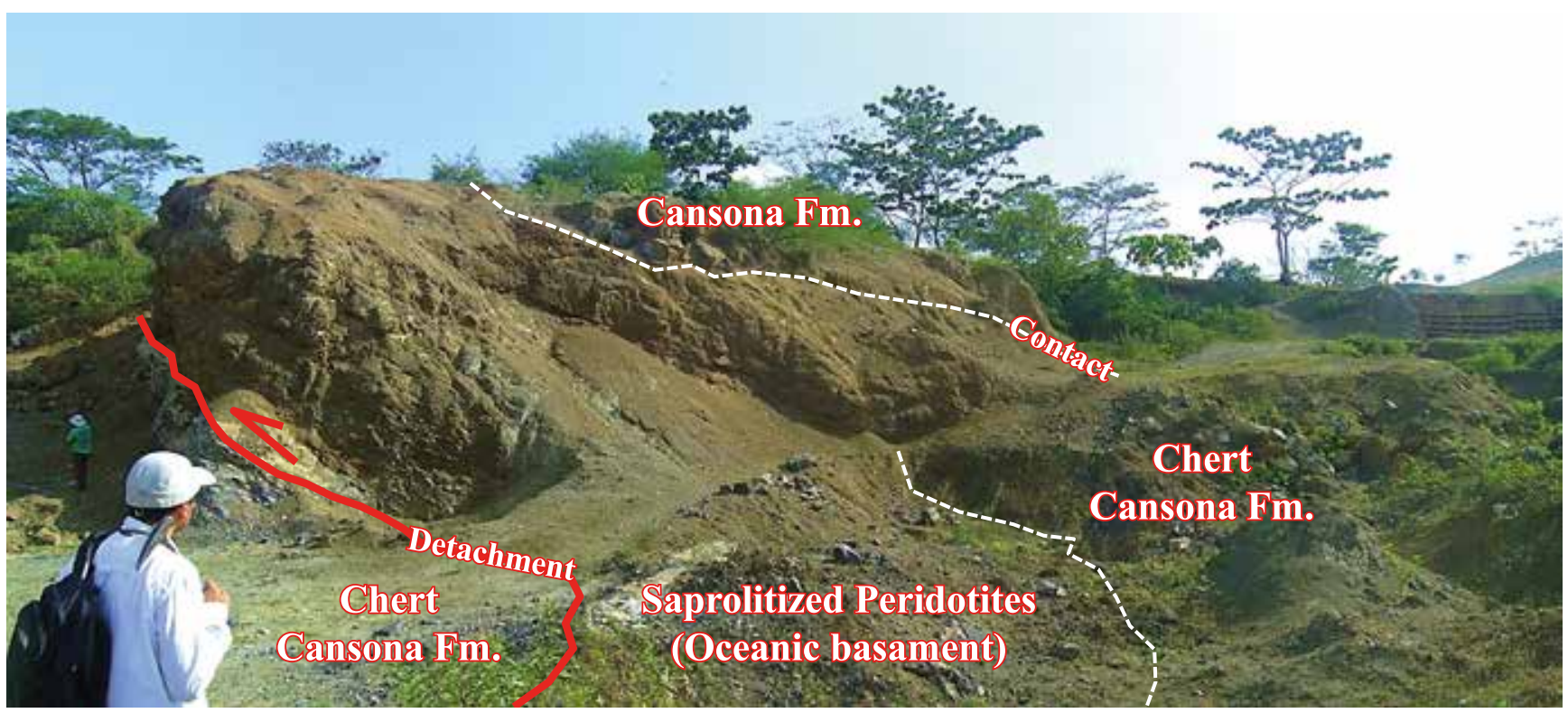

Figure A4.1. Outcrop of imbricated sheet of saprolite and chert of the Cansona Fm. (Late Cretaceous), in the Lorica area (San Carlos quarry). The saprolite presents a greenish gray appearance, little cohesive and spheroidal aspect disjunctions related to supergene alteration processes. 


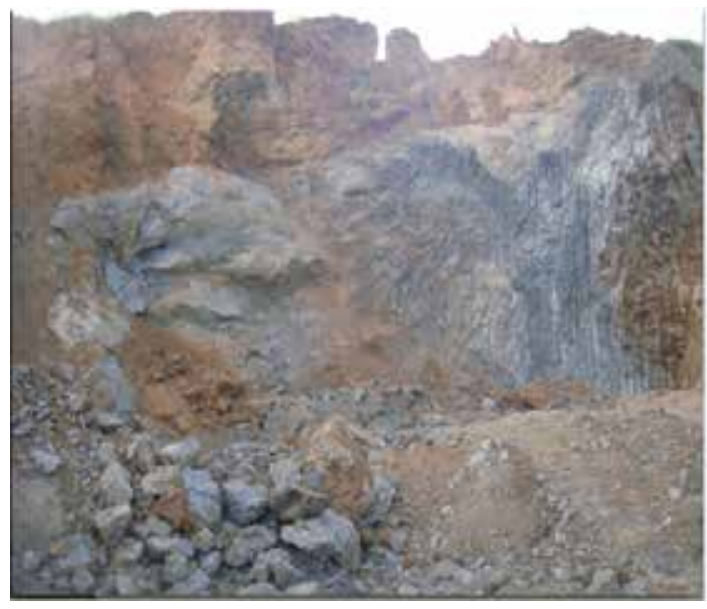

(a)

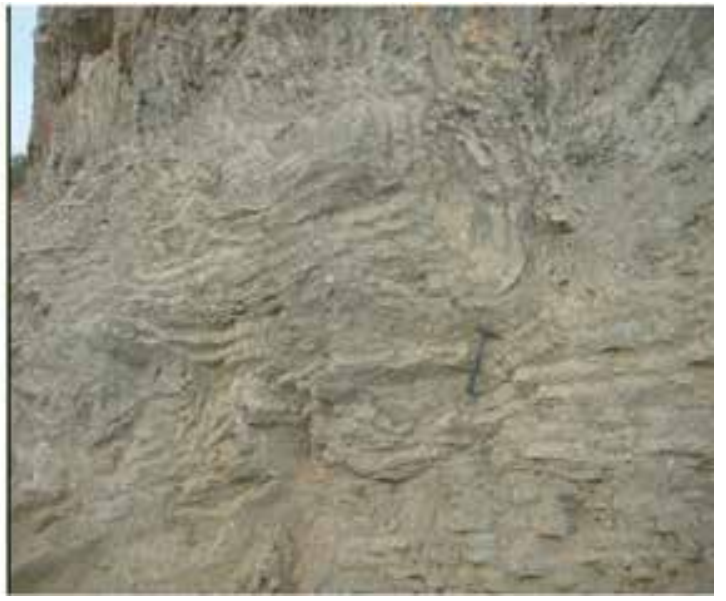

(b)

Figure A4.2. General aspect of sedimentary rocks in the Cansona Formation, outcropping in the Loma Grande Quarry area, where a reddish earthy belt of material is observed (A), considered as a lateritized peridotite. The Cansona Formation rocks are locally refolded (B). 
